\title{
Targeted Palliative Radionuclide Therapy for Metastatic Bone Pain
}

\author{
Reyhaneh Manafi-Farid ${ }^{1}$ (D), Fardad Masoumi ${ }^{2}$ (D), Ghasemali Divband ${ }^{3}$, Bahare Saidi ${ }^{1}$ (D), \\ Bahar Ataeinia ${ }^{4}\left(\mathbb{D}\right.$, Fabian Hertel ${ }^{5}$, Gregor Schweighofer-Zwink ${ }^{6}$, Agnieszka Morgenroth ${ }^{5}$ \\ and Mohsen Beheshti $5,6, *$ (D)
}

1 Research Center for Nuclear Medicine, Shariati Hospital, Tehran University of Medical Sciences, Tehran 1411713135, Iran; manafi_farid_r@hotmail.com (R.M.-F.); bahare_saidi@yahoo.com (B.S.)

2 Department of Orthopedic and Trauma Surgery, Shariati Hospital, Tehran University of Medical Sciences, Tehran 1411713135, Iran; masoumi.fardad@gmail.com

3 Department of Nuclear Medicine, Jam Hospital, Tehran 1588657915, Iran; divband_ali@yahoo.com

4 Athinoula A Martinos Center for Biomedical Imaging, Department of Radiology, Massachusetts General Hospital—Charlestown HealyhCare Center, Boston, MA 02129, USA; bahar.ataeinia@gmail.com

5 Department of Nuclear Medicine, University Hospital, RWTH University, 52074 Aachen, Germany; fhertel@ukaachen.de (F.H.); amorgenroth@ukaachen.de (A.M.)

6 Department of Nuclear Medicine and Endocrinology, Paracelsus Medical University, 5020 Salzburg, Austria; g.schweighofer-zwink@salk.at

* Correspondence: mbeheshti@ukaachen.de ; Tel.: +49-241-8082520

Received: 2 July 2020; Accepted: 31 July 2020; Published: 12 August 2020

\begin{abstract}
Bone metastasis develops in multiple malignancies with a wide range of incidence. The presence of multiple bone metastases, leading to a multitude of complications and poorer prognosis. The corresponding refractory bone pain is still a challenging issue managed through multidisciplinary approaches to enhance the quality of life. Radiopharmaceuticals are mainly used in the latest courses of the disease. Bone-pain palliation with easy-to-administer radionuclides offers advantages, including simultaneous treatment of multiple metastatic foci, the repeatability and also the combination with other therapies. Several $\beta^{-}$- and $\alpha$-emitters as well as pharmaceuticals, from the very first $\left[{ }^{89} \mathrm{Sr}\right]$ strontium-dichloride to recently introduced $\left[{ }^{223} \mathrm{Ra}\right]$ radium-dichloride, are investigated to identify an optimum agent. In addition, the combination of bone-seeking radiopharmaceuticals with chemotherapy or radiotherapy has been employed to enhance the outcome. Radiopharmaceuticals demonstrate an acceptable response rate in pain relief. Nevertheless, survival benefits have been documented in only a limited number of studies. In this review, we provide an overview of bone-seeking radiopharmaceuticals used for bone-pain palliation, their effectiveness and toxicity, as well as the results of the combination with other therapies. Bone-pain palliation with radiopharmaceuticals has been employed for eight decades. However, there are still new aspects yet to be established.
\end{abstract}

Keywords: bone-pain palliation; radionuclide therapy; bone-seeking; $\left.{ }^{89} \mathrm{Sr}\right]$ strontium; $\left[{ }^{153} \mathrm{Sm}\right] \mathrm{Sm}-E D T M P ;\left[{ }^{223} \mathrm{Ra}\right] \mathrm{RaCl}$; [ $\left.{ }^{188} \mathrm{Re}\right] \mathrm{Re}-\mathrm{HEDP} ;\left[{ }^{186} \mathrm{Re}\right] \mathrm{Re}-\mathrm{HEDP} ;\left[{ }^{177} \mathrm{Lu}\right]$ lutetium-EDTMP; combination therapy

\section{Introduction}

Bone metastasis is a common feature of malignancies, particularly in late stages [1,2]. The incidence varies widely in different tumors [1,2]. Up to $70-80 \%$ of the cases reportedly occur in prostate, breast and lung cancers $[3,4]$. The presence of bone metastases implies poorer prognosis, shortens survival and is associated with a multitude of complications, including severe bone pain, pathological fracture, 
spinal cord compression, hypercalcemia, etc. [3,5]. Bone metastases are found using various imaging modalities, namely, plane radiography, computed tomography (CT) and magnetic resonance imaging (MRI), as well as functional examinations employing a wide range of targeted radioligands with single photon emission tomography (SPECT), positron emission tomography (PET) and hybrid SPECT/CT and PET/CT imaging [6,7].

One of the disabling presentations of bone metastases is refractory bone pain. The issue to enhance the quality of life of the patients in their remaining life span continues to be challenging. Bone pain is managed through multidisciplinary approaches using analgesics, bisphosphonates, chemotherapy, external beam radiotherapy (EBRT), immunotherapy, surgery, hormonal treatments and finally, bone-targeted radionuclide therapy [8-10].

Bone-pain palliation with easy-to-administer radionuclides offers advantages including simultaneous treatment of multiple metastatic foci, the repeatability and also the combination with other treatments $[3,10]$. In a systematic review including 57 studies, the response rate was reported $70 \%$ using $\beta^{-}$-emitters [11]. Not only does radionuclide targeted therapy alleviate pain, but it reduces or defers the incidence of skeletal-related events (SRE) [10]. These agents substitute calcium or bind to hydroxyapatite in bones and deliver ionizing radiation to areas with increased osteoblastic activity $[12,13]$. It is of substantial importance to deliver the utmost radiation to metastatic foci while sparing non-affected tissues. Hence, numerous radiopharmaceuticals have been investigated to achieve the optimum result. The extent of metastatic disease, renal function, bone marrow reserve, and, importantly, the availability impact the physicians' choice of an appropriate radiopharmaceutical [3]. A slightly higher response rate has been reported in patients in whom lesions are osteoblastic [13], the skeletal involvement is limited and the performance state is higher [14].

Bone-seeking radiopharmaceuticals emitting $\beta^{-}$-particles have long been used for bone-pain palliation. Meanwhile, $\alpha$-emitting tracers, with $\left[{ }^{223}\right.$ Ra]radium-dichloride at the top, were also developed. Alpha-emitters provide more toxicity for tumoral cells and lesser radiation for surrounding normal tissues [12]. They dispense higher linear energy in a shorter range $(<100 \mu \mathrm{m})$ and predominantly induce permanent DNA double-strand breaks [12]. In addition to bone-seeking agents, other targeted radiopharmaceuticals are used for systemic therapy in nuclear medicine showing therapeutic effects on bone metastases in prostate and neuroendocrine tumors $[15,16]$.

In this review, we aimed to provide an overview of a number of long-established and novel bone-seeking radiopharmaceuticals used for bone-pain palliation, including $\left[{ }^{89} \mathrm{Sr}\right]$ strontium-dichloride, $\left[{ }^{153} \mathrm{Sm}\right]$ samarium, $\left[{ }^{186} \mathrm{Re}\right]$ rhenium, $\left[{ }^{188} \mathrm{Re}\right]$ rhenium, $\left[{ }^{177} \mathrm{Lu}\right]$ lutetium and [ ${ }^{166} \mathrm{Ho}$ ]holmium labeled with bone-seeking agents, as well as [ ${ }^{223} \mathrm{Ra}$ ]radium-dichloride. Noteworthy, [32 P]Phosphorus-orthophosphate and $\left[{ }^{117 \mathrm{~m}} \mathrm{Sn}\right]$-diethylenetriamine pentaacetic acid have traditionally been used; however, their application for bone-pain palliation is currently limited and are not discussed [17,18]. Moreover, the effectiveness and toxicity of the radiopharmaceuticals, as well as the results of the combination therapy with other therapies are also briefly mentioned (Table 1). 
Table 1. Physical characteristics, efficacy and toxicity of radiopharmaceuticals.

\begin{tabular}{|c|c|c|c|c|c|c|c|c|c|c|c|c|}
\hline Radioisotope & Pharmaceutical & $\begin{array}{c}\text { Half-Life } \\
\text { (Days) }\end{array}$ & Emission & $\begin{array}{c}\beta \text { Energy: } \\
\text { Maximum/Mean } \\
(\text { Mev) }\end{array}$ & $\begin{array}{c}\text { Other } \\
\text { Emissions } \\
(\text { KeV) } \\
\text { Abundance } \\
(\%) \\
\end{array}$ & $\begin{array}{c}\text { Range in } \\
\text { Soft-Tissue: } \\
\text { Maximum/Mean } \\
\text { Maximum in } \\
\text { Bone }(\mathrm{mm})\end{array}$ & $\begin{array}{l}\text { Excretion } \\
\text { (Main) }\end{array}$ & $\begin{array}{l}\text { Administration } \\
\text { Dose (MBq) }\end{array}$ & $\begin{array}{l}\text { Response } \\
\text { Rate (\%) }\end{array}$ & $\begin{array}{l}\text { Response } \\
\text { Duration } \\
\text { (Months) }\end{array}$ & $\begin{array}{l}\text { Distinct } \\
\text { Feature }\end{array}$ & References \\
\hline$\left[{ }^{89} \mathrm{Sr}\right]$ strontium & Dichloride & 50.5 & $\beta^{-}$ & $1.46 / 0.583$ & - & $6.7 / 2.4 / 3.0$ & Renal & 150 & $60-95$ & $3-6.5$ & $\begin{array}{c}\text { Longer } \\
\text { typical } \\
\text { duration of } \\
\text { response }\end{array}$ & {$[4,8,9,19-21]$} \\
\hline$\left[{ }^{153} \mathrm{Sm}\right]$ samarium & EDTMP & 1.93 & $\beta^{--}$ & $0.81 / 0.233 /$ & $\gamma: 103(28 \%)$ & $2.5 / 0.6 /-$ & Renal & $37 \mathrm{MBq} / \mathrm{kg}$ & $40-97$ & $2-3$ & $\begin{array}{c}\text { Widely } \\
\text { investigate } \\
\text { and } \\
\text { available }\end{array}$ & {$[10,20,22-25]$} \\
\hline$\left[{ }^{186}\right.$ Re]rhenium & HEDP & 3.7 & $\begin{array}{l}\beta^{-} \\
\gamma \\
\end{array}$ & $1.07 / 0.349$ & $\gamma: 137(9 \%)$ & $4.5 / 1.1 /-$ & Renal & 1295 & $38-82$ & $5-12$ & - & {$[17,26]$} \\
\hline$\left[{ }^{188}\right.$ Re]rhenium & HEDP & 0.7 & $\beta^{--} \gamma$ & $2.12 / 0.64$ & $\gamma: 155(15 \%)$ & $11 / 3 /-$ & Renal & $1100-3300$ & $70-80$ & $3-6$ & $\begin{array}{l}\text { Potential } \\
\text { antitumor } \\
\text { effect }\end{array}$ & {$[18,27-30]$} \\
\hline$\left[{ }^{177} \mathrm{Lu}\right]$ lutetium & $\begin{array}{l}\text { EDTMP } \\
\text { DOTMP } \\
\end{array}$ & 6.73 & $\beta^{-} \gamma$ & $0.489 / 0.133$ & $\begin{array}{c}\gamma: 113(6 \%) \\
208(11 \%)\end{array}$ & $1.7 / 0.23 /-$ & Renal & $1295-2590$ & $77-100$ & $1-4$ & $\begin{array}{c}\text { Widely } \\
\text { available }\end{array}$ & {$[10,21,31]$} \\
\hline$\left[{ }^{166}\right.$ Ho]holmium & $\begin{array}{l}\text { DOTMP } \\
\text { EDTMP }\end{array}$ & 1.12 & $\begin{array}{l}\beta^{-} \\
\gamma \\
\mathrm{x}\end{array}$ & $1.84 / 0.67$ & $\begin{array}{c}\gamma: 81(7 \%) \\
1400(\sim 1 \%) \\
x: 48 \text { to } 55 \\
(10 \%)\end{array}$ & $8.7 / 4.0 / 3.8$ & Renal & $1110 /<55,500$ & - & - & $\begin{array}{l}\text { Efficacy in } \\
\text { bone } \\
\text { marrow } \\
\text { ablation }\end{array}$ & {$[16,31-34]$} \\
\hline${ }^{223}$ Ra]radium & Dichloride & 11.4 & $\begin{array}{l}\alpha \\
\beta^{-} \\
\gamma\end{array}$ & $\begin{array}{c}\text { Maximum } \alpha \\
\text { energy: } 7.53 \\
6.88,6.68,5.78 \\
(95.3 \%)\end{array}$ & $\begin{array}{c}\beta^{-:} 1370 \\
584,1(3.6 \%) \\
\gamma: \\
10-1270 \\
(1.1 \%)\end{array}$ & $<0.1 / 0.05-0.08 /-$ & Gastrointesti & al $55 \mathrm{KBq} / \mathrm{kg} \times 6$ & 29-75 & 1.5 & $\begin{array}{c}\text { Therapeutic } \\
\text { effect }\end{array}$ & {$[10,35-38]$} \\
\hline
\end{tabular}

DOTMP—1,4,7,10-tetraazacyclododecane-1,4,7,10-tetramethylene phosphonate; EDTMP—ethylene diamine tetramethylene phosphonate; HEDP—hydroxyethylidene diphosphonate. 


\section{2. [89. Sr]Strontium-Dichloride $\left(\left[{ }^{89} \mathrm{Sr}\right] \mathrm{SrCl}\right)$}

$\left[{ }^{89} \mathrm{Sr}\right] \mathrm{SrCl}$ is used for bone-pain palliation from 1942 by Pecher [39]. Its efficacy is well-documented in the literature [14,39].

[ ${ }^{89} \mathrm{Sr}$ ]strontium mimics calcium in the body and is taken up into the inorganic bone matrix [8]. Its concentration in the skeleton is a proportion of osteoblastic activity, which is 10-fold higher in metastatic foci [39]. After localization, it remains still in tumoral sites for 100 days [39]. The excretion occurs predominantly from kidneys [19], limiting its use in the setting of renal failure.

According to guidelines, $150 \mathrm{MBq}\left[{ }^{89} \mathrm{Sr}\right] \mathrm{SrCl}$ is administered with slow intravenous infusion [3]. The response rate has been documented to be between 60 to $95 \%$ [40]. In the latest meta-analysis, the overall response rate of $70 \%$ has been reported [11], commencing from the 4-28 days (typically in 14-28 days) of administration and lasting up to 15 months (typically 12-26 weeks) [9,20]. A flushing sensation may occur in case of rapid infusion [3]. The hematological toxicity is the major side-effect of $\left[{ }^{89} \mathrm{Sr}\right] \mathrm{SrCl}$ which is mild, temporary and predominantly consists of myelosuppression $[9,41]$. The nadir occurs between the 12-16 weeks [3], showing resolution in the next six weeks depending on the skeletal tumor extent and bone marrow reserve [20,41]. Follow-up of hematological toxicity is recommended for 12-16 weeks, for the prolonged effect on bone marrow [3].

Despite an acceptable response rate with $\left[{ }^{89} \mathrm{Sr}\right] \mathrm{SrCl}$, a recent meta-analysis showed no significant benefit in prolonging overall survival (OS) or symptomatic SRE-free survival in metastatic castration-resistant prostate cancer (mCRPC) [42]. Besides pain reduction, significant improvement of quality of life has been reported $[43,44]$. However, the improvement in quality of life generally follows pain reduction [45].

Moreover, the combination of $\left[{ }^{89} \mathrm{Sr}\right] \mathrm{SrCl}$ with other therapies has been investigated, mainly in prostate cancer showing the overall response rate of $74 \%$ [11]. Nevertheless, the data considering the currently used agent in mCRPC patients (docetaxel) is scarce, showing improved clinical progression-free survival (PFS), but no effect on OS or SRE-free survival [46].

$\left[{ }^{89} \mathrm{Sr}\right] \mathrm{SrCl}$ and EBRT reportedly appear to perform rather similar in reducing pain and disease progression [47]. In one survey, EBRT slightly outperformed $\left.{ }^{89} \mathrm{Sr}\right] \mathrm{SrCl}$ in terms of OS [47]. In combination, however, the results are controversial. The pain relief was higher in patients receiving both $\left[{ }^{89} \mathrm{Sr}\right] \mathrm{SrCl}$ and EBRT compared to $\left.{ }^{89} \mathrm{Sr}\right] \mathrm{SrCl}$-alone in one study [48], while there was no impact of the addition of $\left[{ }^{89} \mathrm{Sr}\right] \mathrm{SrCl}$ in another [49].

Finally, the combination therapy of $\left[{ }^{89} \mathrm{Sr}\right] \mathrm{SrCl}$ and zoledronic acid for bone metastases has shown superiority in terms of reduction of bone pain, analgesic drug use and time to decrease in pain, as well as improvement of the quality of life compared to $\left[{ }^{89} \mathrm{Sr}\right] \mathrm{SrCl}-$ or zoledronic acid-alone [50]. There has been no significant higher rate of toxicity in the combined method [50]. Moreover, using the combination therapy, pain relief has been reported in $94 \%$ of the patients, tumoricidal effect in $36 \%$, and non-progressive disease in $86 \%$ [51]. Additionally, a significant increase in OS and time to first SRE have been noted with the combination compared to no treatment [52]. In addition, the combination of $\left[{ }^{89} \mathrm{Sr}\right] \mathrm{SrCl}$ and zoledronic acid has revealed survival benefits compared to $\left[{ }^{89} \mathrm{Sr}\right] \mathrm{SrCl}$-alone [53].

Of note, the efficacy of $\left[{ }^{89} \mathrm{Sr}\right] \mathrm{SrCl}$ in bone-pain palliation has been compared to other radiopharmaceuticals revealing no significant difference to $\left[{ }^{153} \mathrm{Sm}\right]$ samarium-ethylene diamine tetramethylene phosphonate and $\quad\left[{ }^{186} \mathrm{Re} /{ }^{188} \mathrm{Re}\right]$ rhenium-hydroxyethylidene diphosphonate $[11,14,18,54] . \quad\left[{ }^{89} \mathrm{Sr}\right] \mathrm{SrCl}$ is still an effective method for bone-pain palliation. The combination with other treatments seem more appealing warranting further investigations to precisely evaluate the impact of these protocols.

\section{3. [153. Sm]Samarium-Ethylene Diamine Tetramethylene Phosphonate ([ $\left.{ }^{153} \mathrm{Sm}\right] \mathrm{Sm}-$ EDTMP)}

$\left[{ }^{153} \mathrm{Sm}\right] \mathrm{Sm}$-EDTMP, a well-known radiopharmaceutical for bone-pain palliation, has been widely used since FDA approval in various osteoblastic metastatic lesions, especially in prostate and breast cancer [55-57]. It rapidly binds to hydroxyapatite crystals, leading to less than $1 \%$ availability in the blood $5 \mathrm{~h}$ after injection. The excretion occurs mainly through the kidneys $[58,59]$. 
Although the maximum tolerable dose of $111 \mathrm{MBq} / \mathrm{kg}$ of body weight has been reported in initial dosimetry studies [58,60], the standard dose of $37 \mathrm{MBq} / \mathrm{kg}$ is well-established [3]. In numerous affirmative studies, a response rate of 40-97\% [22,23,61-63] with a mean of 70\% [11] has been reported. In addition, a decrease in analgesic consumption and improved quality of life has been noted [22-24]. The pain reduction occurs as early as in the first week after injection [23,61], lasting for about two to three months [23-25].

The bone marrow toxicity is mild in most the patients $[61,64]$. The lowest platelet and white blood cell (WBC) counts have been observed in $3-5$ weeks, recovering in $6-8$ weeks after therapy $[23,24,62,64]$. Patients with severe grades of myelotoxicity had predisposing underlying conditions including recent chemotherapy, EBRT or malignant bone marrow involvement [65]. Similarly, mainly minimal and transient bone marrow toxicity has been observed after administering repeated doses of $\left[{ }^{153} \mathrm{Sm}\right] \mathrm{Sm}$-EDTMP $[66,67]$. Other complications are rare with $\left[{ }^{153} \mathrm{Sm}\right] \mathrm{Sm}$-EDTMP compared to systemic therapies like chemotherapy [55].

Moreover, the impact of combining $\left[{ }^{153} \mathrm{Sm}\right] \mathrm{Sm}$-EDTMP with other therapies has been evaluated in a few studies. Adding [ $\left.{ }^{153} \mathrm{Sm}\right] \mathrm{Sm}$-EDTMP to docetaxel for mCRPC patients has revealed favorable results regarding pain control, safety and a decrease in PSA level [68-70]. The PFS has been reported 5.2 to 7 months [68-70].

In addition, combined therapy with local EBRT has resulted in higher analgesic effect than monotherapy with $\left[{ }^{153} \mathrm{Sm}\right] \mathrm{Sm}$-EDTMP, showing no significant difference in bone marrow toxicity in mCRPC [71]. Similar outcomes were reported for combination therapy with bisphosphonates such as zoledronic acid, leading to significantly better pain control [72,73], higher quality of life [73] and shorter time to analgesia [72].

Overall, $\left[{ }^{153} \mathrm{Sm}\right] \mathrm{Sm}$-EDTMP has been successfully used for pain control in more than three decades. It seems the combination with other therapies results in a better outcome. However, the studies are not sufficient to suggest a definite conclusion. Also, earlier initiation of $\left[{ }^{153} \mathrm{Sm}\right] \mathrm{Sm}$-EDTMP may be more effective [74]. Hence, the optimal timing of administration of $\left.{ }^{153} \mathrm{Sm}\right] \mathrm{Sm}$-EDTMP requires further assessment.

\section{4. [186. Re]Rhenium-Hydroxyethylidene Diphosphonate ([$\left.{ }^{186} \operatorname{Re}\right]$ Re-HEDP)}

$\left[{ }^{186} \operatorname{Re}\right]$ rhenium is a combined $\beta^{-} / \gamma$-emitter isotope labelled with a phosphonate complex (HEDP), localized in bones attaching hydroxyapatite crystals [17]. The shorter physical half-life of 3.8 days may produce a faster onset of pain relief in comparison to the radiopharmaceuticals with longer half-lives [75]. The usual recommended dose of [ ${ }^{186} \mathrm{Re}$ Re-HEDP for bone-pain palliation therapy is $1295 \mathrm{MBq}(35 \mathrm{mCi}$ ) [26]. Approximately $70 \%$ of the administrated activity is excreted in the urine within the first $24 \mathrm{~h}$ after injection [17].

The successful pain reduction has been noted in different studies using $\left[{ }^{186} \operatorname{Re}\right] \operatorname{Re}-H E D P$ [76-78]. However, the large cohorts addressing [ $\left.{ }^{186} \mathrm{Re}\right] \mathrm{Re}-\mathrm{HEDP}$ is lacking. The overall response rate has been reported to be between $38 \%$ and $82 \%$ using doses of $1295 \mathrm{MBq}$ to $1406 \mathrm{MBq}$ [17]. While it has been mainly used for breast and prostate cancers, limited studies in other malignancies, such as lung cancer, have revealed similar performance [78-80]. Additionally, improved quality of life and reduction of analgesic medication has been reported [79,81]. Usually, the response occurs in 1-3 weeks after injection [76,82] and lasts for 3 weeks to $12-15$ months [76,81-83]. After therapy, a temporary decrease in platelets and WBC counts frequently occurs $[76,78,83]$, reaches the nadir after $1-5$ weeks $[26,83]$ and recovers in the following $2-4$ weeks $[83,84]$.

Although survival benefits have not been proved for $\beta^{-}$-emitters, a study on $57 \mathrm{mCRPC}$ patients, high-dose treatment ( $>3500 \mathrm{MBq}$ ) has shown an increase in OS, in the univariate analysis. However, in the multivariate analysis, only the lower disease burden was associated with increased OS [85]. There is literally little studies evaluating the combination with other therapies. However, the safety in co-administration with docetaxel and zoledronic acid has been documented $[86,87]$. 
No significant difference in rates of pain palliation, therapeutic efficacy or the possibility of toxicity has been reported for [ ${ }^{186}$ Re]Re-HEDP compare to other $\beta^{-}$-emitters, including [ ${ }^{188}$ Re]Re-HEDP, $\left[{ }^{153} \mathrm{Sm}\right] \mathrm{Sm}-\mathrm{EDTMP}$ and $\left[{ }^{89} \mathrm{Sr}\right] \mathrm{SrCl}[54,88]$. Hence, $\left[{ }^{186} \mathrm{Re}\right] \mathrm{Re}-\mathrm{HEDP}$ can be considered as a reasonable choice for bone-pain palliation therapy regarding logistic feasibility. Further studies are required to establish its role in combination with other treatments.

\section{5. [188. Re]Rhenium-Hydroxyethylidene Diphosphonate ([ $\left.\left.{ }^{188} \operatorname{Re}\right] \operatorname{Re}-H E D P\right)$}

$\left[{ }^{188} \mathrm{Re}\right] \mathrm{Re}-\mathrm{HEDP}$ is a bone-seeking therapeutic radiopharmaceutical with favorable characteristics for application in bone-pain palliation therapy [89]. In clinical studies with [ ${ }^{188} \mathrm{Re}$ Re-HEDP, various dosage have been used, mainly between $1300-4400 \mathrm{MBq}[27,28,90]$. The maximum tolerated dose of $3300 \mathrm{MBq}$ has been proposed in one study [29]. Approximately $40 \%$ of the administered activity is cleared within $8 \mathrm{~h}$ after injection, via the urinary system, resulting in a low radiation-dose to the whole-body [30]. Approximately $40 \%$ is localized in the skeleton at $24 \mathrm{~h}$ [90]. The localization in the bone metastases, however, is rather prolonged (half-life of $269 \pm 166 \mathrm{~h}$ in bone metastases versus short whole-body biologic half-life of $51 \pm 43 \mathrm{~h}$ ) [30].

The response rate of $70-80 \%$ has been reported in painful bone metastases in various malignancies [90-94]. In addition, an increase in Karnofsky performance score and improved quality of life have been noticed after treatment with [ ${ }^{188}$ Re]Re-HEDP $[28,93-95]$. Generally, serious hematological side-effects are not expected $[92,95,96]$. The nadir for platelet and WBC counts occurs in $2-5$ weeks and resolves in $8-12$ weeks after therapy $[28,54,94]$.

Although $\beta^{-}$-emitters are so-called "palliative", repeated doses of $\left[{ }^{188} \operatorname{Re}\right] \operatorname{Re}-\mathrm{HEDP}$, compared to a single administration, have shown improvement in PFS and OS [97], as well as a reduction in prostate-specific antigen (PSA) levels in approximately half of the patients [97,98]. Another retrospective study on sixty mCRPC patients has revealed that repeated treatment with $\left[{ }^{188}\right.$ Re]Re-HEDP can improve OS up to 15.6 months [99]. The apparent antitumoral effect may be explained by higher $\beta^{-}$-energy and tissue penetration, as well as a higher dose rate of $\left[{ }^{188}\right.$ Re]Re-HEDP.

Moreover, the efficacy of combination therapy has been investigated. Repeated doses of $\left[{ }^{186} \mathrm{Re}\right.$ Re-HEDP combined with docetaxel and prednisone versus docetaxel and prednisone alone have shown no significant improvement in PFS nor pain scores in 88 mCRPC patients [100]. In contrast, the combination with pamidronate in 48 breast cancer patients has revealed a better therapeutic effect, compared to either [ ${ }^{188}$ Re]Re-HEDP or pamidronate alone [101]. Furthermore, zoledronic acid has been labeled with $\left[{ }^{188} \mathrm{Re}\right] \mathrm{Re}$ and has demonstrated promising results requiring confirmation in larger studies [102].

In conclusion, $\left[{ }^{188} \operatorname{Re}\right] \operatorname{Re}-$ HEDP has not been approved in many countries for clinical use, and the number of prospective trials with large populations is limited. However, respecting physical characteristics, favorable pain control, the potential impact on OS, availability (on-site generator) and cost-effectiveness, it seems a proper radiopharmaceutical for bone-pain palliation and deserves further investigations.

\section{6. [177. Lu]Lutetium-Ethylene Diamine Tetramethylene Phosphonate $\left(\left[{ }^{177} \mathrm{Lu}\right] \mathrm{Lu}-\mathrm{EDTMP}\right)$}

$\left[{ }^{177} \mathrm{Lu}\right]$ Lutetium labelled with somatostatin analogs and prostate-specific membrane antigen (PSMA) are generally used for the treatment of soft-tissue and bone metastases of neuroendocrine tumors and prostate cancer, respectively, revealing acceptable response rates [15,16]. Beside to this common application, $\left[{ }^{177} \mathrm{Lu}\right] \mathrm{Lu}-\mathrm{EDTMP}$ has been studied as a safe and effective potential palliative therapy in painful bone metastases, regarding binding to hydroxyapatite crystals, rapid skeletal accumulation and minimal uptake in other organs [103]. [177 Lu]Lu-DOTMP (1,4,7,10-tetraazacyclododecane-1,4,7,10-tetramethylene phosphonate) has also been investigated revealing rather similar characteristics to $\left[{ }^{177} \mathrm{Lu}\right] \mathrm{Lu}-\mathrm{EDTMP}$. Yet, the latter exhibits slightly higher skeletal uptake as well as retention in the liver and kidneys [33]. 
The combined complete and partial response rate of $77-100 \%$ has been documented in different studies using $\left[{ }^{177} \mathrm{Lu}\right] \mathrm{Lu}-E D T M P$ for pain palliation of bone metastases $[21,31,34]$. The decrease in pain has been reported as early as 8-14 days after therapy lasting up to 12 weeks [31,34]. In addition, significant improvement in the quality of life has been noted in patients received $\left[{ }^{177} \mathrm{Lu}\right] \mathrm{Lu}-E D T M P[21,31]$. Comparing low- and high-dose therapy (1295 vs. $\left.2590 \mathrm{MBq}\right)$ in two studies, higher response rates have been reported in the high-dose group, although not statistically significant $[21,31]$. The hematological toxicity is the major complication which ends up with a decrease in peripheral blood cell count with a nadir in 4-8 weeks and gradual recovery in 12 weeks [21]. This side-effect is commonly insignificant [21,34]; However, transient grade III/IV hematotoxicity has been reported in $23 \%$ of patients [31].

Moreover, the effect of $\left[{ }^{177} \mathrm{Lu}\right] \mathrm{Lu}-\mathrm{EDTMP}$ has been compared to $\left[{ }^{153} \mathrm{Sm}\right] \mathrm{Sm}-\mathrm{EDTMP}$. Reportedly, they both have subjected bone metastases to similar radiation doses [104]. Likewise, the response rate of approximately $75-80 \%$ has been noted for both radiopharmaceuticals [104-106]. In addition, the cocktail therapy of $\left[{ }^{177} \mathrm{Lu}\right] \mathrm{Lu}-/\left[{ }^{153} \mathrm{Sm}\right] \mathrm{Sm}-\mathrm{EDTMP}$ has shown safety in administration and pain relief/reduction in 24/25 patients [107].

$\left[{ }^{177} \mathrm{Lu}\right] \mathrm{Lu}$ labeled with zoledronic acid $\left(\left[{ }^{177} \mathrm{Lu}\right] \mathrm{Lu}-\mathrm{DOTA}{ }^{\mathrm{ZOL}}\right)$ is another investigational radiopharmaceutical with promising preliminary biodistribution and post-therapy dosimetry results. It also possess a potential theragnostic application (labeled with $\left[{ }^{68} \mathrm{Ga}\right]$ gallium-DOTA ${ }^{\mathrm{ZOL}}$ ) for treatment of bone metastases [108].

To recapitulate, $\left[{ }^{177} \mathrm{Lu}\right]$ lutetium may be more available considering the established use in radionuclide therapy for neuroendocrine tumors and prostate cancers. Also, the features of relatively inexpensive $\left[{ }^{177} \mathrm{Lu}\right]$ lutetium, such as favorable half-life, production in high-specific activity, efficient therapeutic $\beta^{-}$-particles, longer effect with a single administration, lower radiation of bone marrow and sufficient $\gamma$-photons for imaging make it an interesting radioisotope in bone-pain palliation therapy $[32-34,109,110]$. The impact of $\left[{ }^{177} \mathrm{Lu}\right] \mathrm{Lu}-$ phosphonate complexes in increasing survival indices is not addressed, fairly. More studies are required to investigate the clinical value of these radiopharmaceuticals, especially in combination with other therapies.

\section{7. [166. Ho]holmium-Ethylene Diamine Tetramethylene Phosphonate $\left(\left[{ }^{166}\right.\right.$ Ho $]$ Ho-EDTMP)}

Different phosphonate complexes have been labelled with $\left[{ }^{166} \mathrm{Ho}\right]$ holmium targeting bone and bone marrow lesions [111-114]. [ ${ }^{166} \mathrm{Ho}$ holmium is an inexpensive $\beta^{-}$-emitter, majorly used in the treatment of multiple myeloma [112,115].

$\left[{ }^{166} \mathrm{Ho}\right]$ Ho-phosphonates are taken up rapidly by bone and show $[112,114,116]$ significant in-vitro stability after $72 \mathrm{~h}$ [112]. The free cation and the complex are excreted via kidneys [112]. One of the advantages of [ $\left.{ }^{166} \mathrm{Ho}\right] \mathrm{Ho}$-phosphonates is the negligible accumulation in extra-skeletal organs [112]. A dose of $1110 \mathrm{MBq}$ has been used for therapy [114]. Also, administered activity less than 55,500 MBq estimated to be safe for kidneys to be used for bone marrow ablation in multiple myeloma patients [114]. Its potential efficacy in bone-pain palliation of multiple myeloma and bone metastases is being contemplated $[112,116,117]$. In a pilot study, $\left[{ }^{166} \mathrm{Ho}\right] \mathrm{Ho}-\mathrm{DOTMP}$ was used for the treatment of bone metastases in breast cancer patients showing median time to progression of 10.4 months [118]. In addition, owing to the remarkably higher radiation dose to the bone marrow, combination of $\left[{ }^{166} \mathrm{Dy}\right]$ dysprosium/[ $\left.{ }^{166} \mathrm{Ho}\right] \mathrm{Ho}-\mathrm{EDTMP}$ is proposed as an agent for bone marrow ablation [113].

Finally, the successful experience with radioisotopes labeled with phosphonate in addition to physical characteristics of [ $\left.{ }^{166} \mathrm{Ho}\right]$ Ho maybe encouraging to perform further studies investigating the efficacy of $\left[{ }^{166} \mathrm{Ho}\right] \mathrm{Ho}$-phosphonates in bone-pain palliation/treatment of multiple metastases or multiple myeloma. In addition, its potential in bone marrow ablation is intriguing. However, far more studies are needed before these investigational radiopharmaceuticals become a part of the clinical practice. 


\section{8. [223. Ra]radium-Dichloride $\left(\left[{ }^{223} \mathrm{Ra}\right] \mathrm{RaCl}\right)$}

Similar to $\left[{ }^{89} \mathrm{Sr}\right]$ strontium, $\left[{ }^{223} \mathrm{Ra}\right] \mathrm{radium}$ is a calcium mimetic isotope and deposits on hydroxyapatite [12]. [ ${ }^{223} \mathrm{Ra}$ ]Ra with a half-life of 11.4 days decays via a cascade of $\alpha, \beta^{-}$and $\gamma$ emissions [12]. Ninety-four percent of the total decay energy is released from $\alpha$-particles [12].

The approved injection dose is $55 \mathrm{KBq} / \mathrm{kg}$ body weight every month for a total of 6 cycles [119]. The excretion is mainly through gastrointestinal system, raising concern in the co-existence of constipation and inflammation in bowels [35].

Given the substantially shorter range of $\left[{ }^{223} \mathrm{Ra}\right] \mathrm{Ra}$ in tissues, hematological toxicity is expected to be less in comparison with $\beta^{-}$-emitters [36]. Mild and reversible myelosuppression occurs with a nadir in 2-4 weeks after intravenous injection resolving in 6 weeks after administration $[10,20]$. In addition, diarrhea, nausea and vomiting occur in $\geq 10 \%$ of cases [35].

$\left[{ }^{223} \mathrm{Ra}\right] \mathrm{RaCl}$ has been primarily evaluated for pain palliation of bone metastases, which has demonstrated a reduction of bone pain in $40-71 \%$ of patients in one study and $29-75 \%$ in another, showing a trend of higher response rates with the currently approved dose [37,38]. Also, significantly improved quality of life and higher pain relief, as well as longer time to first symptomatic SRE, need for EBRT and initial opioid use have been demonstrated [120,121] [35,121,122]. The typical time to decrease in pain intensity and duration of pain palliation is 1-8 and 6 weeks, respectively [20]. $\left[{ }^{223} \mathrm{Ra}\right] \mathrm{RaCl}$ results in pain relief only in a portion of patients; however, the completion of all 6 courses of the therapy is indicated for achieving OS benefit in most cases [123]. Discontinuation of [ $\left.{ }^{223} \mathrm{Ra}\right] \mathrm{RaCl}$ therapy should be considered in cases of significant hematologic derangements as well as evidence of rapid disease progression and visceral metastases [124].

Recently, the probability of benefits of $\left[{ }^{223} \mathrm{Ra}\right] \mathrm{RaCl}$ administration in earlier stages of bone metastases in $\mathrm{mCRPC}$ has been proposed showing that patients with lower numbers of bone metastases have better outcome [125]. Metastases to the axial skeleton and the value of alkaline phosphatase were reported as significant predictors of the survival [125]. In addition, in a study, asymptomatic patients with two or more skeletal lesions have revealed more favorable results, demonstrating lower adverse events [126]. These findings may provoke further studies using $\left[{ }^{223} \mathrm{Ra}\right] \mathrm{RaCl}$ at initial diagnosis of bone metastases.

Evaluation of response to therapy for bone metastases is challenging. This is not readily possible with CT or bone scintigraphy. Although PET/CT imaging using bone-seeking and tumor-specific tracers are not yet approved for this indication, the published studies, as well as our clinical experience revealed promising role of PET/CT in the assessment of treatment response (Figures 1 and 2) [7,127]. Also, recent studies have shown that diffusion-weighted MRI may be of value in this setting [128]. Other traditional measures, like a decline in PSA level, are not reliable means to assess response following therapy with $\left[{ }^{223} \mathrm{Ra}\right] \mathrm{RaCl}[127]$.

Although it is well-known that visceral metastases preclude patients from participation in $\left.{ }^{223} \mathrm{Ra}\right] \mathrm{RaCl}$ therapy, an investigator has a contradictory view and propose that although survival benefit may be lower in these group of patients, it does not necessarily translate to poor response to therapy [129].

Therapy of mCRPC includes different strategies involving androgen receptor inhibitors, EBRT, chemotherapy (docetaxel) and immunotherapy [130]. Androgen receptor inhibitors are the main modality of treatment in mCRPC patients. However, patients can become resistant to both enzalutamide and abiraterone $[127,131]$. Considering the different mechanism of action, $\left[{ }^{223} \mathrm{Ra}\right] \mathrm{RaCl}$ can become a qualified alternative to the common practice, switching to another androgen receptor inhibitor in cases of drug resistance [13].

The combination of hormonal therapy and $\left[{ }^{223} \mathrm{Ra}\right] \mathrm{RaCl}$ is the subject of ongoing clinical studies [130]. [ ${ }^{223} \mathrm{Ra}$ ] RaCl has been used in combination with either abiraterone or enzalutamide; however, its impact on OS is still under investigation [132,133]. Preliminary data have demonstrated increase in survival with combination therapy. These studies are still ongoing to establish the impact on survival. Noteworthy, an improvement in event-free survival in mCRPC patients treated 
with abiraterone, corticosteroids and $\left[{ }^{223} \mathrm{Ra}\right] \mathrm{RaCl}$ has not been achieved [134]. Interestingly, in the combination group, an increased risk of fracture has been reported, compared to the placebo arm [134].

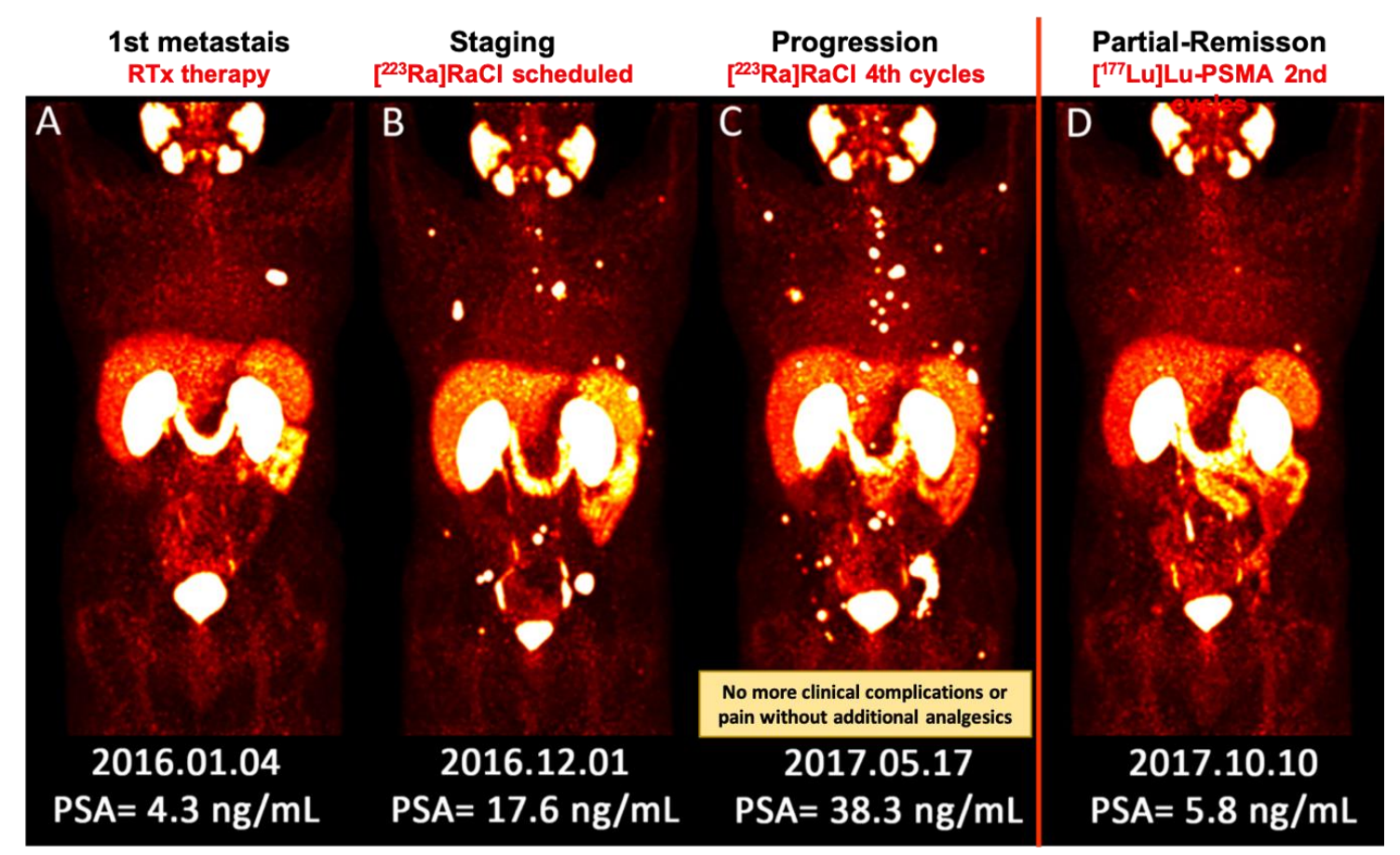

Figure 1. (A-D) Sequential images (MIP) of $\left[{ }^{68} \mathrm{Ga}\right] \mathrm{Ga}$-PSMA PET/CT scan from a patient with metastatic prostate cancer. (A) He underwent local radiotherapy for single bone metastasis in the left $6^{\text {th }}$ rib; (B) After approximately one year, he developed multiple painful bone metastases. $\mathrm{He}$ received 4 cycles of $\left[{ }^{223} \mathrm{Ra}\right] \mathrm{RaCl}$ therapy. Pain reduced significantly and he no longer needed analgesic medication; (C) Nevertheless, the PSA level was apparently rising and the disease was progressing. The therapeutic plan was switched to $\left[{ }^{177} \mathrm{Lu}\right] \mathrm{Lu}-\mathrm{PSMA}$. Afterwards, the response to therapy was clearly captured by $\left[{ }^{68} \mathrm{Ga}\right] \mathrm{Ga}-\mathrm{PSMA}$ PET/CT after 2 cycles of $\left[{ }^{177} \mathrm{Lu}\right] \mathrm{Lu}-\mathrm{PSMA}$ therapy, which was concomitant with the significant biochemical response (decrease in PSA level). [ $\left.{ }^{177} \mathrm{Lu}\right] \mathrm{Lu}-\mathrm{PSMA}:\left[{ }^{177}\right.$ lutetium]Lu-prostate-specific membrane antigen; $\left[{ }^{223} \mathrm{Ra}\right] \mathrm{RaCl}$ - ${ }^{223}$ radium]ra-dichloride; $\left[{ }^{68} \mathrm{Ga}\right] \mathrm{Ga}-\mathrm{PSMA}$ PET/CT-[ ${ }^{68}$ gallium] Ga-prostate-specific membrane antigen positron emission tomography/computed tomography; MIP-maximum intensity projection; PSA — prostate-specific antigen; RTx—radiotherapy.

Moreover, EBRT has been used safely along with $\left[{ }^{223} \mathrm{Ra}\right] \mathrm{RaCl}$ [127]. EBRT prior to $\left[{ }^{223} \mathrm{Ra}\right] \mathrm{RaCl}$ administration has not shown an association with compromised hematologic reserve [135]. The different mechanism of action of these two modalities advocates more studies on the combination therapy to evaluate the impact on the outcome.

Additionally, bone-pain palliation with denosumab or bisphosphonate in combination with $\left[{ }^{223} \mathrm{Ra}\right] \mathrm{RaCl}$ has been investigated. Increase in OS has been observed only with denosumab [132]. In addition, the treatment with $\left[{ }^{223} \mathrm{Ra}\right] \mathrm{RaCl}$ plus bisphosphonates has prolonged time to symptomatic SRE [136].

The safety of docetaxel administration prior to $\left[{ }^{223} \mathrm{Ra}\right] \mathrm{RaCl}$ therapy has previously been studied [137]. Although this sequence of therapy seems to be well-tolerated, there has been an increased incidence of grade III/IV thrombocytopenia as well as a risk of decreased time to SRE, in the $\left[{ }^{223} \mathrm{Ra}\right] \mathrm{RaCl}$ group [137]. However, [ $\left.{ }^{223} \mathrm{Ra}\right] \mathrm{RaCl}$ has increased survival, regardless of previous docetaxel treatment [137]. In addition, the concomitant treatment with docetaxel and [ $\left.{ }^{223} \mathrm{Ra}\right] \mathrm{RaCl}$, compared to docetaxel, has demonstrated a favorable antitumor activity has prolonged biochemical suppression [138] and time to progression [139]. 


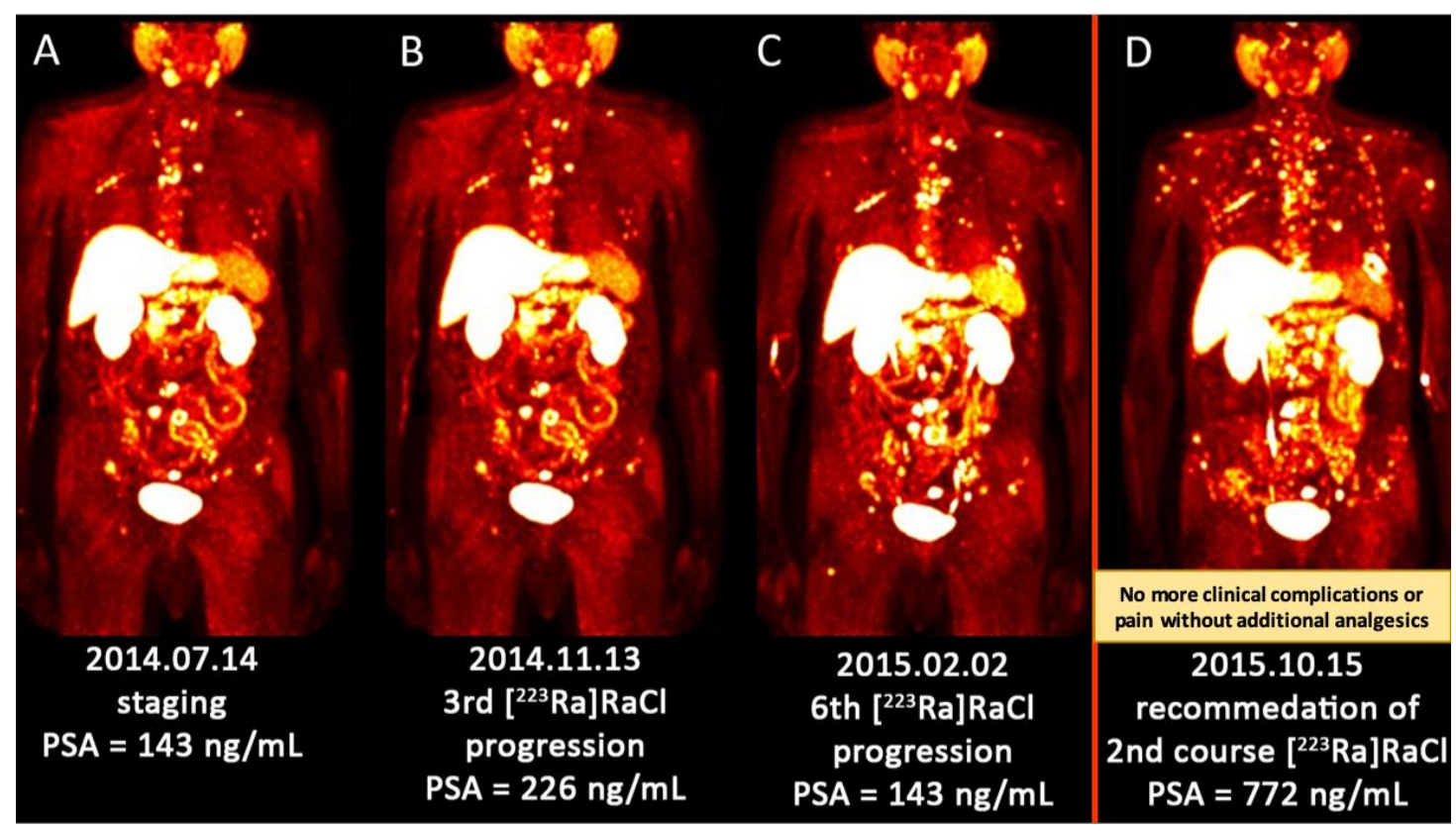

Figure 2. (A-D) Sequential images (MIP) of $\left[{ }^{18} \mathrm{~F}\right] \mathrm{FCH}$ PET/CT scan from a patient with multiple metastatic prostate cancer. (A) There were multiple bone metastases predominantly in the axial skeleton. He received 3 cycles of $\left[{ }^{223} \mathrm{Ra}\right] \mathrm{RaCl}$; (B) The PSA was increasing (more than $150 \%$ ) after 3 cycles of $\left[{ }^{223} \mathrm{Ra}\right] \mathrm{RaCl}$. He finished 6 cycles of $\left[{ }^{223} \mathrm{Ra}\right] \mathrm{RaCl}$ therapy. He became pain-free and ceased to take analgesic medication; (C) The metabolism imaging showed rather stable metabolic disease although the PSA level was slightly increased; (D) After 8 months of follow-up, there was an aggressive anatomic, metabolic and biochemical progression of the disease. Regarding the previous and slow disease progression under $\left[{ }^{223} \mathrm{Ra}\right] \mathrm{RaCl}$, he was recommended to receive the 2 nd course of $\left[{ }^{223} \mathrm{Ra}\right] \mathrm{RaCl}$ treatment/palliation. $\left[{ }^{18} \mathrm{~F}\right] \mathrm{FCH} \mathrm{PET} / \mathrm{CT}-\left[{ }^{18}\right.$ Fluorine $]$ fluorocholine positron emission tomography/computed tomography; MIP-maximum intensity projection; PSA—prostate-specific antigen; $\left[{ }^{223} \mathrm{Ra}\right] \mathrm{RaCl}-\left[{ }^{223}\right.$ radium $]$ ra-dichloride.

The choice between the sequence of $\left[{ }^{223} \mathrm{Ra}\right] \mathrm{RaCl}$ and docetaxel therapy is mainly based on the involved organs. The absence of visceral involvement favors the use of $\left[{ }^{223} \mathrm{Ra}\right] \mathrm{RaCl}$ as the primary agent [13]. Further larger studies on the risks and benefits of concurrent administration of chemotherapy and $\left[{ }^{223} \mathrm{Ra}\right] \mathrm{RaCl}$ are required. The same is true for co-administration of $\beta^{-}$-emitting bone-targeted therapies and $\left[{ }^{223} \mathrm{Ra}\right] \mathrm{RaCl}$, as their safety profile needs further investigation [127].

Other newer agents such as programmed cell death (PD-1) inhibitors have also been approved for types of mCRPC that are microsatellite instability (MSI)-high and DNA mismatch repair-deficient [130]. The combination of these agents (atezolizumab) with $\left[{ }^{223} \mathrm{Ra}\right] \mathrm{RaCl}$ in $\mathrm{mCRPC}$ with bone metastases is currently under investigation [130]. Other newer agents include DNA damage response inhibitors, such as Olaparib, that has revealed a favorable response rate in mCRPC patients, in a phase II trial. Ongoing trials are also investigating the effect of these newer agents in association with [223 Ra]RaCl [130].

Not surprisingly, $\left[{ }^{223} \mathrm{Ra}\right] \mathrm{RaCl}$ is the subject of ongoing trials in other bone dominant metastatic cancers such as breast [140,141] and lung cancers [142]. In a phase II trial, [ $\left.{ }^{223} \mathrm{Ra}\right] \mathrm{RaCl}$ has been administered with different hormonal therapy agents [141]. The primary end-point was disease control at 9 months, achieved in 49\% of patients [141]. In addition, the study evaluating the efficacy of combined therapy of $\left[{ }^{223} \mathrm{Ra}\right] \mathrm{RaCl}$ in association with hormonal therapy and a chemotherapy drug (capecitabine) is still in progress [140].

Ultimately, the studies are in progress, evaluating the further benefits of $\left.\left[{ }^{223} \mathrm{Ra}\right] \mathrm{RaCl} .{ }^{223} \mathrm{Ra}\right] \mathrm{RaCl}$ seems a promising therapeutic agent beside its palliative effects, used alone or in combination with 
other treatments or palliative agents in MCRPC patients and it may find its way in other bone dominant metastatic malignancies.

\section{Discussion}

Bone metastases develop in approximately $30 \%$ of cancer patients and occur in up to $60-90 \%$ in late phases [26]. Therapeutic approaches have been extensively investigated to reach for an optimum method. Since the first introduction of radionuclide therapy in bone-pain palliation in the $1940 \mathrm{~s}$, numerable radioisotopes and pharmaceuticals have been exploited to target the bone lesions and alleviate the pain. Each demonstrates particular characteristics, benefits and drawbacks (Figure 3). However, the choice extremely rests on the logistic feasibility of the tracer and then on the patient's status (renal function, bone marrow reserve), cancer extent (extraskeletal lesions, the bulk of the tumor) and physical properties of radioisotopes (Figure 4).

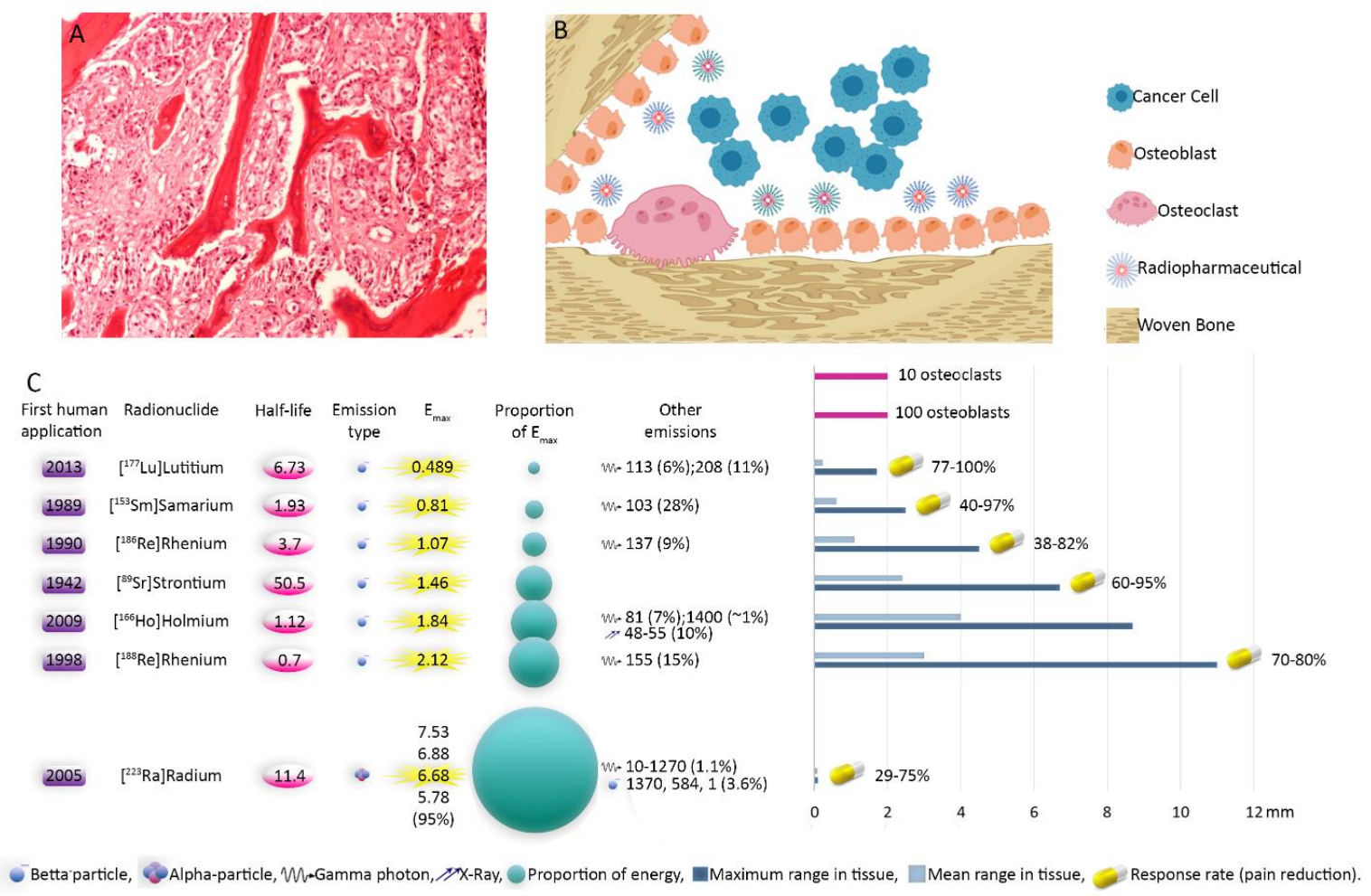

Figure 3. Illustration of bone metastases and physical characteristics of radiopharmaceuticals. Cancerous cells from prostate origin produce cytokines activating osteoblasts. On the other hand, their homing is facilitated by secreted factors from osteoblasts. In addition, chemoattractants created by newly formed bone matrix increase the invasiveness of cancer cells. This cycle continues destructing the bone. Bone-seeking radiopharmaceuticals reside in regions with bone turn over. Accumulation of radiopharmaceuticals in the osteoblastically active regions, which is induced or increased significantly by tumoral cells infiltration, leads in mainly irradiation of metastatic sites with only minimal impact on the normal tissues. Eventually, the tumoral tissues shrink, osteoblastic activity is inhibited and stimulation of the periosteal pain receptors is reduced [10,31]. (A) Histopathology image of bone metastasis; (B) schematic illustration of bone metastasis with predominant osteoblastic proliferation. Note the accumulation of radiopharmaceuticals in areas with osteoblastic activity. Depending on the range of the agent, the cancerous and normal cells will be affected; (C) physical characteristics and efficiency of radiopharmaceuticals. The response rates (Table 1) pertain to bone-seeking pharmaceuticals labeled with the mentioned radionuclides. $\mathrm{E}_{\max }$ : Maximum particle energy. First human application [21,89,118,143-145]. 


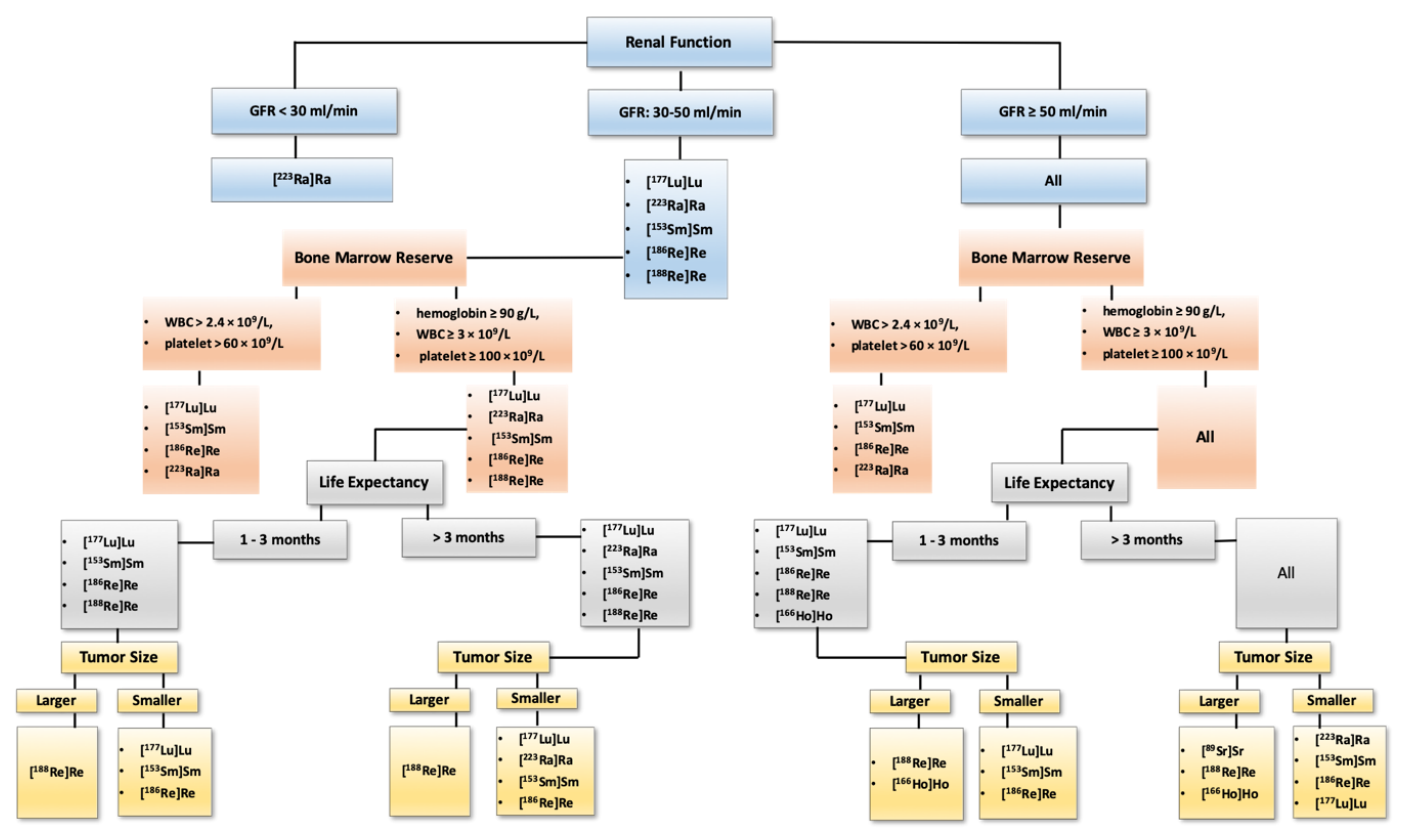

Figure 4. A proposed algorithm for selecting an appropriate radiopharmaceutical for bone-pain palliation therapy. Bone-pain palliation with radiopharmaceuticals is offered when the metastatic sites are widespread or not amenable to the local therapy. Prostate cancer with bone metastases accompanied with minimal lymph node metastases should be treated with $\left[{ }^{223} \mathrm{Ra}\right] \mathrm{RaCl}$. Those with concomitant visceral metastases should be considered for treatment with [ $\left.{ }^{177} \mathrm{Lu}\right] \mathrm{Lu}-\mathrm{PSMA}$. Metastatic thyroid cancer, neuroendocrine tumors, pheochromocytomas and paragangliomas must be treated with associated targeted radiopharmaceuticals, namely [131I]Iodine, $\left[{ }^{177} \mathrm{Lu}\right] \mathrm{Lu} /\left[{ }^{90} \mathrm{Y}\right] \mathrm{Y}$-conjugated peptides and $\left.{ }^{131} \mathrm{I}\right] \mathrm{I}-\mathrm{MIBG}$, respectively. For other malignancies with painful bone metastases the above algorithm is proposed. Noteworthy, only widely established agents are [ $\left.{ }^{223} \mathrm{Ra}\right] \mathrm{RaCl}$ (for prostate cancer), $\left[{ }^{153} \mathrm{Sm}\right] \mathrm{Sm}-\mathrm{EDTMP}$ and $\left[{ }^{89} \mathrm{Sr}\right] \mathrm{SrCl}$. In conjunction with radiopharmaceuticals, other hormonal therapies (e.g., androgen deprivation therapy for prostate cancer, octreotide for neuroendocrine tumors, etc.) should be continued. Besides radiopharmaceuticals, concomitant use of bisphosphonates and denosumab, as well as other therapies should be considered in the context of trials. This proposed general approach is based on our personal experience; however, decision making should be based on local experiences, availability of the radioligands, national regulations and guidelines as well as reimbursement provided by health systems.

No significant superiority in pain reduction has been documented using different $\beta^{-}$-emitters [18]. The $\alpha$-emitter, $\left[{ }^{223} \mathrm{Ra}\right] \mathrm{RaCl}$, also shows a response rate of $50-60 \%$ [146], not beyond the reported range for $\beta^{-}$-emitters. However, the effects on extending survival parameters make $\left[{ }^{223} \mathrm{Ra}\right] \mathrm{RaCl}$ a more appealing agent to be employed.

Noteworthy, patients must comply with requirements for radionuclide treatment, that is, to have osteoblastic activity in symptomatic bone metastases, sufficient renal function, bone marrow reserve and life expectancy [147]. In addition, presence of spinal cord compression, high risk of fracture in weight-bearing bones, pregnancy and breastfeeding are contraindication for radionuclide therapy $[3,147]$.

\subsection{Concomitant Extraskeletal Involvement}

When the disease is not confined to the skeleton, other than exclusively bone-seeking agents are mandatory to target all tumoral lesions. Disease-specific radiopharmaceuticals (including $\left[{ }^{177} \mathrm{Lu}\right] \mathrm{Lu}-\mathrm{PSMA}$ in prostate cancer, $\left[{ }^{177} \mathrm{Lu}\right] \mathrm{Lu} /\left[{ }^{90} \mathrm{Y}\right] \mathrm{Y}$-conjugated peptides in neuroendocrine tumors, $\left[{ }^{131} \mathrm{I}\right]$ Iodine in differentiated thyroid cancer, $\left[{ }^{131} \mathrm{I}\right] \mathrm{I}-\mathrm{MIBG}$ in pheochromocytomas/paragangliomas, etc.) provide simultaneous radiation to the skeletal and visceral lesions. In addition, bone-seeking agents 
may be administered when the disease-specific radiopharmaceuticals fail to reduce pain, considerably. This hypothetical application needs trials to depict safety and efficacy.

\subsection{Life Expectancy}

Patients with very short life expectancy may not be optimal candidates for bone-pain palliation with radiopharmaceuticals since the response to therapy commonly commences with a delay of 1-4 weeks with reports of exacerbation of pain (flare-response) in a few first days [3]. If patients with shorter predicted life expectancy are to receive this therapy, radioisotopes with shorter half-lives would be better options, such as [ $\left.{ }^{188} \mathrm{Re}\right]$ rhenium and $\left[{ }^{153} \mathrm{Sm}\right]$ samarium, as well as $\left[{ }^{186} \mathrm{Re}\right]$ rhenium and maybe $\left[{ }^{166} \mathrm{Ho}\right]$ holmium. In contrast, in case of predicted long life expectancy, other than [ ${ }^{223}$ Ra]radium and $\left[{ }^{89} \mathrm{Sr}\right]$ strontium revealing longer palliation effects may be proper options. In addition, repeated doses of other radiopharmaceuticals or combination with other therapies may be reasonable.

\subsection{Bone Marrow Status}

Bone marrow reserve can generally be the dose-limiting factor. Before administration of bone-seeking agents, hematological indices typically should meet the values of hemoglobin $\geq 90 \mathrm{~g} / \mathrm{L}$, WBC $\geq 3 \times 10^{9} / \mathrm{L}$ and platelet $\geq 100 \times 10^{9} / \mathrm{L}$ in most of the cases [3]. These indices are as follows for [ $\left.{ }^{223} \mathrm{Ra}\right] \mathrm{RaCl}$ : hemoglobin $\geq 10 \mathrm{~g} / \mathrm{L}$, absolute neutrophil count $\geq 1.5 \times 10^{9} / \mathrm{L}$ and platelet $\geq 100 \times 10^{9} / \mathrm{L}$ [35]. In patients with compromised bone marrow reserve, radiopharmaceuticals with less hematological toxicities or shorter particle range are favored, including $\left[{ }^{153} \mathrm{Sm}\right]$ samarium and $\left[{ }^{177} \mathrm{Lu}\right]$ lutetium, as well as $\left[{ }^{223}\right.$ Ra]radium.

\subsection{Renal Function}

The clearance of radiopharmaceuticals excreted via kidneys is prolonged in renal insufficiency, increasing the whole-body dose and myelosuppressive side effect [3]. Hence, in case of mild to moderate decreased renal function, $\left[{ }^{223} \mathrm{Ra}\right]$ radium (with negligible renal excretion) and $\beta^{-}$-emitters with a shorter half-life and with reduced doses $\left(\left[{ }^{153} \mathrm{Sm}\right]\right.$ samarium, $\left[{ }^{186} \mathrm{Re}\right]$ rhenium and maybe $\left[{ }^{177} \mathrm{Lu}\right]$ lutetium, $\left[{ }^{188} \mathrm{Re}\right]$ rhenium or $\left[{ }^{166} \mathrm{Ho}\right]$ holmium) are favored.

\subsection{Tumor Size}

The size of the tumoral lesions can also play a role in opting the proper radiopharmaceutical. The energy of the emitted $\beta^{-}$-particle is proportional to the range of penetration in the tissue. Hence, radiopharmaceuticals with higher $\beta^{-}$-particle energy, such as $\left[{ }^{188}\right.$ Re]rhenium and $\left[{ }^{166} \mathrm{Ho}\right]$ holmium can be more effective in larger lesions than small ones. As a rule of thumb, $\left[{ }^{177} \mathrm{Lu}\right]$ lutetium and $\left[{ }^{153} \mathrm{Sm}\right]$ samarium can be used in small-sized lesions. Moreover, $\alpha$-particles deliver substantially high energy in a short distance and can be employed in small-sized metastases, as well.

Historically, regarding the merely palliative effects of traditional $\beta^{-}$-emitters, radiopharmaceuticals become a part of patient treatment when physicians are at the end of their rope and the life expectancy is poor. However, this approach may change in the guidelines, in the future, regarding: first, $\beta^{-}$-emitters are more effective when they are used in early stages and limited skeletal involvement and when the patient's performance state is higher [74,85]; second, the combination therapy is being more evaluated and demonstrate promising results. Other than chemo- or radiotherapy, combination with bisphosphonates or denosumab, a RANK ligand inhibitor, are barley investigated; third, it is well-known that $\alpha$-emitters are more toxic for tumoral cells and show significant survival benefits.

Future directions are concisely mentioned for each radiopharmaceutical in the pertinent section. On the whole, further studies evaluating the role of radiopharmaceuticals in the earlier course of the disease and the combination with other therapies may clarify the role of nuclear medicine in the palliation or treatment of bone metastases. 


\section{Conclusions}

In summary, the management of painful bone metastases is still a challenging issue. Bone-pain palliation with $\beta^{-}$-emitting isotopes is being conducted for decades, revealing acceptable results. Several radiopharmaceuticals have been and still are being investigated to find an optimum agent. Based on the current data, each therapeutic radioligand has its own advantages and limitations without any substantial superiority over others. The impact of radionuclide therapy on overall and disease-free survival as well as SRE has been shown in the published studies. However, further investigations with larger patient populations are needed to confirm their prognostic roles. Nevertheless, the introduction of [ $\left.{ }^{223} \mathrm{Ra}\right]$ radium with its advantageous impact on survival cast a shadow over other radiopharmaceuticals; however, unfortunately, the expensive $\left[{ }^{223}\right.$ Ra]radium is not globally available. Combination treatments using bone-seeking radiopharmaceuticals with other therapies have demonstrated safety and favorable results in some studies. Hence, further investigations are mandatory to establish the role of bone-seeking and tumor-targeted radionuclide therapy,optimal timing and combined protocols, in the palliation or treatment of bone metastases.

Author Contributions: Conceptualization: M.B.; Data and Writing: R.M.-F., F.M., B.S., G.D. and B.A. original draft preparation: R.M.-F.; review \& editing, M.B., R.M.-F., F.H., G.S.-Z. and A.M.; visualization: R.M.-F.; supervision, Mohsen Beheshti. All authors have read and agreed to the published version of the manuscript.

Funding: This research received no external funding.

Acknowledgments: We wish to express our deep appreciation and gratitude to Werner Langsteger, Department of Nuclear Medicine and Endocrinology, PET-CT Center LINZ, St. Vincent's Hospital, Linz, AUSTRIA, for providing sequential PET/CT images of the patients, as well as Elham Mirzaian, Department of Pathology, Shariati Hospital, Tehran University of Medical Sciences, Tehran, Iran, for providing the histopathology image that greatly improved the manuscript.

Conflicts of Interest: The authors declare no conflicts of interest.

\section{References}

1. Hernandez, R.K.; Wade, S.W.; Reich, A.; Pirolli, M.; Liede, A.; Lyman, G.H. Incidence of bone metastases in patients with solid tumors: Analysis of oncology electronic medical records in the United States. BMC Cancer 2018, 18, 44. [CrossRef] [PubMed]

2. Heindel, W.; Gübitz, R.; Vieth, V.; Weckesser, M.; Schober, O.; Schäfers, M. The diagnostic imaging of bone metastases. Dtsch. Ärzteblatt Int. 2014, 111, 741. [CrossRef] [PubMed]

3. Handkiewicz-Junak, D.; Poeppel, T.D.; Bodei, L.; Aktolun, C.; Ezziddin, S.; Giammarile, F.; Delgado-Bolton, R.C.; Gabriel, M. EANM guidelines for radionuclide therapy of bone metastases with beta-emitting radionuclides. Eur. J. Nucl. Med. Mol. Imaging 2018, 45, 846-859. [CrossRef] [PubMed]

4. $\quad$ Li, S.; Peng, Y.; Weinhandl, E.D.; Blaes, A.H.; Cetin, K.; Chia, V.M.; Stryker, S.; Pinzone, J.J.; Acquavella, J.F.; Arneson, T.J. Estimated number of prevalent cases of metastatic bone disease in the US adult population. Clin. Epidemiol. 2012, 4, 87. [PubMed]

5. Michael, H.-H.; Tsai, Y.-Y.; Hoffe, S.E. Overview of diagnosis and management of metastatic disease to bone. Cancer Control 2012, 19, 84-91. [CrossRef]

6. Histed, S.N.; Lindenberg, M.L.; Mena, E.; Turkbey, B.; Choyke, P.L.; Kurdziel, K.A. Review of functional/anatomic imaging in oncology. Nucl. Med. Commun. 2012, 33, 349. [CrossRef]

7. Karamzade-Ziarati, N.; Manafi-Farid, R.; Ataeinia, B.; Langsteger, W.; Pirich, C.; Mottaghy, F.M.; Beheshti, M. Molecular imaging of bone metastases using tumor-targeted tracers. Q. J. Nucl. Med. Mol. Imaging 2019, 63, 136-149. [CrossRef]

8. McEwan, A. Use of radionuclides for the palliation of bone metastases. Semin. Radiat. Oncol. 2000, 8, $103-114$. [CrossRef]

9. Finlay, I.G.; Mason, M.D.; Shelley, M. Radioisotopes for the palliation of metastatic bone cancer: A systematic review. Lancet Oncol. 2005, 6, 392-400. [CrossRef]

10. Florimonte, L.; Dellavedova, L.; Maffioli, L.S. Radium-223 dichloride in clinical practice: A review. Eur. J. Nucl. Med. Mol. Imaging 2016, 43, 1896-1909. [CrossRef] 
11. D'Angelo, G.; Sciuto, R.; Salvatori, M.; Sperduti, I.; Mantini, G.; Maini, C.L.; Mariani, G. Targeted "bone-seeking" radiopharmaceuticals for palliative treatment of bone metastases: A systematic review and meta-analysis. $Q$. J. Nucl. Med. Mol. Imaging 2012, 56, 538-543. [PubMed]

12. Bruland, Ø.S.; Nilsson, S.; Fisher, D.R.; Larsen, R.H. High-linear energy transfer irradiation targeted to skeletal metastases by the $\alpha$-emitter 223Ra: Adjuvant or alternative to conventional modalities? Clin. Cancer Res. 2006, 12, 6250s-6257s. [CrossRef] [PubMed]

13. Baczyk, M.; Czepczynski, R.; Milecki, P.; Pisarek, M.; Oleksa, R.; Sowinski, J. 89Sr versus 153Sm-EDTMP: Comparison of treatment efficacy of painful bone metastases in prostate and breast carcinoma. Nucl. Med. Commun. 2007, 28, 245-250. [CrossRef] [PubMed]

14. Dafermou, A.; Colamussi, P.; Giganti, M.; Cittanti, C.; Bestagno, M.; Piffanelli, A. A multicentre observational study of radionuclide therapy in patients with painful bone metastases of prostate cancer. Eur. J. Nucl. Med. 2001, 28, 788-798. [CrossRef]

15. Strosberg, J.; El-Haddad, G.; Wolin, E.; Hendifar, A.; Yao, J.; Chasen, B.; Mittra, E.; Kunz, P.L.; Kulke, M.H.; Jacene, H. Phase 3 trial of 177Lu-Dotatate for midgut neuroendocrine tumors. New Engl. J. Med. 2017, 376, $125-135$. [CrossRef]

16. Emmett, L.; Willowson, K.; Violet, J.; Shin, J.; Blanksby, A.; Lee, J. Lutetium 177 PSMA radionuclide therapy for men with prostate cancer: A review of the current literature and discussion of practical aspects of therapy. J. Med. Radiat. Sci. 2017, 64, 52-60. [CrossRef]

17. Choi, J.Y. Treatment of Bone Metastasis with Bone-Targeting Radiopharmaceuticals. Nucl. Med. Mol. Imaging 2018, 52, 200-207. [CrossRef]

18. Liberal, F.D.G.; Tavares, A.A.S.; Tavares, J.M.R. Palliative treatment of metastatic bone pain with radiopharmaceuticals: A perspective beyond Strontium-89 and Samarium-153. Appl. Radiat. Isot. 2016, 110, 87-99. [CrossRef]

19. Goyal, J.; Antonarakis, E.S. Bone-targeting radiopharmaceuticals for the treatment of prostate cancer with bone metastases. Cancer Lett. 2012, 323, 135-146. [CrossRef]

20. Ahmadzadehfar, H.; Essler, M.; Rahbar, K.; Afshar-Oromieh, A. Radionuclide Therapy for bone metastases: Utility of scintigraphy and PET imaging for treatment planning. PET Clin. 2018, 13, 491-503. [CrossRef]

21. Yuan, J.; Liu, C.; Liu, X.; Wang, Y.; Kuai, D.; Zhang, G.; Zaknun, J.J. Efficacy and safety of 177Lu-EDTMP in bone metastatic pain palliation in breast cancer and hormone refractory prostate cancer: A phase II study. Clin. Nucl. Med. 2013, 38, 88-92. [CrossRef] [PubMed]

22. Bauman, G.; Charette, M.; Reid, R.; Sathya, J. Radiopharmaceuticals for the palliation of painful bone metastases-A systematic review. Radiother. Oncol. 2005, 75, 258-270. [CrossRef] [PubMed]

23. Sartor, O.; Reid, R.H.; Hoskin, P.J.; Quick, D.P.; Ell, P.J.; Coleman, R.E.; Kotler, J.A.; Freeman, L.M.; Olivier, P.; Group, Q.S.S. Samarium-153-Lexidronam complex for treatment of painful bone metastases in hormone-refractory prostate cancer. Urology 2004, 63, 940-945. [CrossRef] [PubMed]

24. Tripathi, M.; Singhal, T.; Chandrasekhar, N.; Kumar, P.; Bal, C.; Jhulka, P.; Bandopadhyaya, G.; Malhotra, A. Samarium-153 ethylenediamine tetramethylene phosphonate therapy for bone pain palliation in skeletal metastases. Indian J. Cancer 2006, 43, 86. [CrossRef] [PubMed]

25. Ayati, N.; Aryana, K.; Jalilian, A.; Hoseinnejad, T.; Samani, A.B.; Ayati, Z.; Shariati, F.; Zakavi, S.R. Treatment efficacy of 153Sm-EDTMP for painful bone metastasis. Asia Ocean. J. Nucl. Med. Biol. 2013, 1, 27.

26. Bodei, L.; Lam, M.; Chiesa, C.; Flux, G.; Brans, B.; Chiti, A.; Giammarile, F. EANM procedure guideline for treatment of refractory metastatic bone pain. Eur. J. Nucl. Med. Mol. Imaging 2008, 35, 1934. [CrossRef] [PubMed]

27. Liepe, K. 188Re-HEDP therapy in the therapy of painful bone metastases. World J. Nucl. Med. 2018, 17, $133-138$. [CrossRef]

28. Shinto, A.S.; Mallia, M.B.; Kameswaran, M.; Kamaleshwaran, K.; Joseph, J.; Radhakrishnan, E.; Upadhyay, I.V.; Subramaniam, R.; Sairam, M.; Banerjee, S. Clinical utility of 188Rhenium-hydroxyethylidene-1, 1-diphosphonate as a bone pain palliative in multiple malignancies. World J. Nucl. Med. 2018, 17, 228. [CrossRef]

29. Palmedo, H.; Guhlke, S.; Bender, H.; Sartor, J.; Schoeneich, G.; Risse, J.; Grünwald, F.; Knapp, F.F., Jr.; Biersack, H.J. Dose escalation study with rhenium-188 hydroxyethylidene diphosphonate in prostate cancer patients with osseous metastases. Eur. J. Nucl. Med. Mol. Imaging 2000, 27, 123-130. [CrossRef] 
30. Liepe, K.; Kropp, J.; Runge, R.; Kotzerke, J. Therapeutic efficiency of rhenium-188-HEDP in human prostate cancer skeletal metastases. Br. J. Cancer 2003, 89, 625-629. [CrossRef]

31. Agarwal, K.K.; Singla, S.; Arora, G.; Bal, C. 177Lu-EDTMP for palliation of pain from bone metastases in patients with prostate and breast cancer: A phase II study. Eur. J. Nucl. Med. Mol. Imaging 2015, 42, 79-88. [CrossRef] [PubMed]

32. Mazzarri, S.; Guidoccio, F.; Mariani, G. The emerging potential of 177Lu-EDTMP: An attractive novel option for radiometabolic therapy of skeletal metastases. Clin. Transl. Imaging 2015, 3, 167-168. [CrossRef]

33. Chakraborty, S.; Das, T.; Sarma, H.D.; Venkatesh, M.; Banerjee, S. Comparative studies of 177Lu-EDTMP and 177Lu-DOTMP as potential agents for palliative radiotherapy of bone metastasis. Appl. Radiat. Isot. 2008, 66, 1196-1205. [CrossRef] [PubMed]

34. Alavi, M.; Omidvari, S.; Mehdizadeh, A.; Jalilian, A.R.; Bahrami-Samani, A. Metastatic Bone Pain Palliation using (177)Lu-Ethylenediaminetetramethylene Phosphonic Acid. World J. Nucl. Med. 2015, 14, 109-115. [CrossRef] [PubMed]

35. Poeppel, T.D.; Handkiewicz-Junak, D.; Andreeff, M.; Becherer, A.; Bockisch, A.; Fricke, E.; Geworski, L.; Heinzel, A.; Krause, B.J.; Krause, T.; et al. EANM guideline for radionuclide therapy with radium-223 of metastatic castration-resistant prostate cancer. Eur. J. Nucl. Med. Mol. Imaging 2018, 45, 824-845. [CrossRef]

36. Carrasquillo, J.A.; O’Donoghue, J.A.; Pandit-Taskar, N.; Humm, J.L.; Rathkopf, D.E.; Slovin, S.F.; Williamson, M.J.; Lacuna, K.; Aksnes, A.-K.; Larson, S.M.; et al. Phase I pharmacokinetic and biodistribution study with escalating doses of 223 Ra-dichloride in men with castration-resistant metastatic prostate cancer. Eur. J. Nucl. Med. Mol. Imaging 2013, 40, 1384-1393. [CrossRef]

37. Nilsson, S.; Strang, P.; Aksnes, A.; Franzèn, L.; Olivier, P.; Pecking, A.; Staffurth, J.; Vasanthan, S.; Andersson, C.; Bruland, $\varnothing$. A randomized, dose-response, multicenter phase II study of radium-223 chloride for the palliation of painful bone metastases in patients with castration-resistant prostate cancer. Eur. J. Cancer 2012, 48, 678-686. [CrossRef]

38. Parker, C.C.; Pascoe, S.; Chodacki, A.; O’Sullivan, J.M.; Germá, J.R.; O’Bryan-Tear, C.G.; Haider, T.; Hoskin, P. A randomized, double-blind, dose-finding, multicenter, phase 2 study of radium chloride (Ra 223) in patients with bone metastases and castration-resistant prostate cancer. Eur. Urol. 2013, 63, 189-197. [CrossRef]

39. Robinson, R.G.; Spicer, J.A.; Preston, D.F.; Wegst, A.V.; Martin, N.L. Treatment of metastatic bone pain with strontium-89. Int. J. Radiat. Appl. Instrum. Part B Nucl. Med. Biol. 1987, 14, 219-222. [CrossRef]

40. Sciuto, R.; Festa, A.; Pasqualoni, R.; Semprebene, A.; Rea, S.; Bergomi, S.; Maini, C.L. Metastatic bone pain palliation with 89-Sr and 186-Re-HEDP in breast cancer patients. Breast Cancer Res. Treat. 2001, 66, 101-109. [CrossRef]

41. Lewington, V.J. Bone-seeking radionuclides for therapy. J. Nucl. Med. 2005, 46, 38S-47S. [PubMed]

42. Terrisse, S.; Karamouza, E.; Parker, C.C.; Sartor, A.O.; James, N.D.; Pirrie, S.; Collette, L.; Tombal, B.F.; Chahoud, J.; Smeland, S. Overall Survival in Men With Bone Metastases From Castration-Resistant Prostate Cancer Treated With Bone-Targeting Radioisotopes: A Meta-analysis of Individual Patient Data From Randomized Clinical Trials. JAMA Oncol. 2020, 6, 206-216. [CrossRef]

43. Kurosaka, S.; Satoh, T.; Chow, E.; Asano, Y.; Tabata, K.-I.; Kimura, M.; Tsumura, H.; Matsumoto, K.; Ishiyama, H.; Inoue, Y.; et al. EORTC QLQ-BM22 and QLQ-C30 quality of life scores in patients with painful bone metastases of prostate cancer treated with strontium-89 radionuclide therapy. Ann. Nucl. Med. 2012, 26, 485-491. [CrossRef] [PubMed]

44. Kraeber-Bodéré, F.; Campion, L.; Rousseau, C.; Bourdin, S.; Chatal, J.-F.; Resche, I. Treatment of bone metastases of prostate cancer with strontium-89 chloride: Efficacy in relation to the degree of bone involvement. Eur. J. Nucl. Med. 2000, 27, 1487-1493. [CrossRef] [PubMed]

45. Turner, S.L.; Gruenewald, S.; Spry, N.; Gebski, V. Less pain does equal better quality of life following strontium-89 therapy for metastatic prostate cancer. Br. J. Cancer 2001, 84, 297-302. [CrossRef]

46. James, N.D.; Pirrie, S.J.; Pope, A.M.; Barton, D.; Andronis, L.; Goranitis, I.; Collins, S.; Daunton, A.; McLaren, D.; O'Sullivan, J. Clinical Outcomes and Survival Following Treatment of Metastatic Castrate-Refractory Prostate Cancer With Docetaxel Alone or With Strontium-89, Zoledronic Acid, or Both: The TRAPEZE Randomized Clinical Trial. JAMA Oncol. 2016, 2, 493-499. [CrossRef]

47. Oosterhof, G.; Roberts, J.; de Reijke, T.M.; Engelholm, S.; Horenblas, S.; von der Maase, H.; Neymark, N.; Debois, M.; Collette, L. Strontium89 chloride versus palliative local field radiotherapy in patients with 
hormonal escaped prostate cancer: A phase III study of the European Organisation for Research and Treatment of Cancer Genitourinary Group. Eur. Urol. 2003, 44, 519-526. [CrossRef]

48. Heianna, J.; Toita, T.; Endo, W.; Kasuya, G.; Ariga, T.; Hashimoto, S.; Maemoto, H.; Terui, K.; Miura, N.; Togashi, A.; et al. Concurrent use of strontium- 89 with external beam radiotherapy for multiple bone metastases: Early experience. Ann. Nucl. Med. 2015, 29, 848-853. [CrossRef]

49. Smeland, S.; Erikstein, B.; Aas, M.; Skovlund, E.; Hess, S.L.; Fosså, S.D. Role of strontium-89 as adjuvant to palliative external beam radiotherapy is questionable: Results of a double-blind randomized study. Int. J. Radiat. Oncol. Biol. Phys. 2003, 56, 1397-1404. [CrossRef]

50. Storto, G.; Klain, M.; Paone, G.; Liuzzi, R.; Molino, L.; Marinelli, A.; Soricelli, A.; Pace, L.; Salvatore, M. Combined therapy of $\mathrm{Sr}-89$ and zoledronic acid in patients with painful bone metastases. Bone 2006, 39, 35-41. [CrossRef]

51. Baba, K.; Kaida, H.; Hattori, C.; Muraki, K.; Kugiyama, T.; Fujita, H.; Ishibashi, M. Tumoricidal effect and pain relief after concurrent therapy by strontium- 89 chloride and zoledronic acid for bone metastases. Hell. J. Nucl. Med. 2018, 21, 15-23. [PubMed]

52. Wang, Y.; Tao, H.; Yu, X.; Wang, Z.; Wang, M. Clinical significance of zoledronic acid and strontium-89 in patients with asymptomatic bone metastases from non-small-cell lung cancer. Clin. Lung Cancer 2013, 14, $254-260$. [CrossRef] [PubMed]

53. Hu, Z.; Tian, Y.; Li, W.; Ruan, Y.; Zeng, F. The efficacy and safety of zoledronic acid and strontium-89 in treating non-small cell lung cancer: A systematic review and meta-analysis of randomized controlled trials. Support. Care Cancer 2019, 28, 3291-3301. [CrossRef] [PubMed]

54. Liepe, K.; Kotzerke, J. A comparative study of 188Re-HEDP, 186Re-HEDP, 153Sm-EDTMP and 89Sr in the treatment of painful skeletal metastases. Nucl. Med. Commun. 2007, 28, 623-630. [CrossRef]

55. Anderson, P.; Nunez, R. Samarium lexidronam (153Sm-EDTMP): Skeletal radiation for osteoblastic bone metastases and osteosarcoma. Expert Rev. Anticancer Ther. 2007, 7, 1517-1527. [CrossRef]

56. Maini, C.L.; Bergomi, S.; Romano, L.; Sciuto, R. 153Sm-EDTMP for bone pain palliation in skeletal metastases. Eur. J. Nucl. Med. Mol. Imaging 2004, 31, S171-S178. [CrossRef]

57. Kolesnikov-Gauthier, H.; Lemoine, N.; Tresch-Bruneel, E.; Olivier, A.; Oudoux, A.; Penel, N. Efficacy and safety of ${ }^{153} \mathrm{Sm}$-EDTMP as treatment of painful bone metastasis: A large single-center study. Support. Care Cancer 2018, 26, 751-758. [CrossRef]

58. Eary, J.F.; Collins, C.; Stabin, M.; Vernon, C.; Petersdorf, S.; Baker, M.; Hartnett, S.; Ferency, S.; Addison, S.J.; Appelbaum, F.; et al. Samarium-153-EDTMP biodistribution and dosimetry estimation. J. Nucl. Med. 1993, 34, 1031-1036.

59. Bayouth, J.E.; Macey, D.J.; Kasi, L.P.; Fossella, F.V. Dosimetry and toxicity of samarium-153-EDTMP administered for bone pain due to skeletal metastases. J. Nucl. Med. 1994, 35, 63-69.

60. Collins, C.; Eary, J.F.; Donaldson, G.; Vernon, C.; Bush, N.E.; Petersdorf, S.; Livingston, R.B.; Gordon, E.E.; Chapman, C.R.; Appelbaum, F.R. Samarium-153-EDTMP in bone metastases of hormone refractory prostate carcinoma: A phase I/II trial. J. Nucl. Med. 1993, 34, 1839-1844.

61. Correa-González, L.; de Murphy, C.A.; Pichardo-Romero, P.; Pedraza-López, M.; Moreno-García, C.; Correa-Hernández, L. 153Sm-EDTMP for pain relief of bone metastases from prostate and breast cancer and other malignancies. Arch. Med. Res. 2014, 45, 301-308. [CrossRef] [PubMed]

62. Sapienza, M.T.; Ono, C.R.; Guimarães, M.I.C.; Watanabe, T.; Costa, P.A.; Buchpiguel, C.A. Retrospective evaluation of bone pain palliation after samarium-153-EDTMP therapy. Rev. Hosp. Clin. 2004, 59, 321-328. [CrossRef] [PubMed]

63. Tian, J.H.; Zhang, J.M.; Hou, Q.T.; Oyang, Q.H.; Wang, J.M.; Luan, Z.S.; Chuan, L.; He, Y.J. Multicentre trial on the efficacy and toxicity of single-dose samarium-153-ethylene diamine tetramethylene phosphonate as a palliative treatment for painful skeletal metastases in China. Eur. J. Nucl. Med. 1999, 26, 2-7. [CrossRef] [PubMed]

64. Resche, I.; Chatal, J.-F.; Pecking, A.; Ell, P.; Duchesne, G.; Rubens, R.; Fogelman, I.; Houston, S.; Fauser, A.; Fischer, M. A dose-controlled study of $153 \mathrm{Sm}$-Ethylenediaminetetramethylenephosphonate (EDTMP) in the treatment of patients with painful bone metastase. Eur. J. Cancer 1997, 33, 1583-1591. [CrossRef]

65. Serafini, A.N. Samarium Sm-153 lexidronam for the palliation of bone pain associated with metastases. Cancer 2000, 88, 2934-2939. [CrossRef]

66. Sartor, O.; Reid, R.H.; Bushnell, D.L.; Quick, D.P.; Ell, P.J. Safety and efficacy of repeat administration of samarium Sm-153 lexidronam to patients with metastatic bone pain. Cancer 2007, 109, 637-643. [CrossRef] 
67. Turner, J.H.; Claringbold, P.G. A phase II study of treatment of painful multifocal skeletal metastases with single and repeated dose samarium-153 ethylenediaminetetramethylene phosphonate. Eur. J. Cancer Clin. Oncol. 1991, 27, 1084-1086. [CrossRef]

68. Fizazi, K.; Beuzeboc, P.; Lumbroso, J.; Haddad, V.; Massard, C.; Gross-Goupil, M.; Di Palma, M.; Escudier, B.; Theodore, C.; Loriot, Y.; et al. Phase II trial of consolidation docetaxel and samarium-153 in patients with bone metastases from castration-resistant prostate cancer. J. Clin. Oncol. 2009, 27, 2429-2435. [CrossRef]

69. Lin, J.; Sinibaldi, V.J.; Carducci, M.A.; Denmeade, S.; Song, D.; Deweese, T.; Eisenberger, M.A. Phase I trial with a combination of docetaxel and ${ }^{153} \mathrm{Sm}$-lexidronam in patients with castration-resistant metastatic prostate cancer. Urol. Oncol. 2011, 29, 670-675. [CrossRef]

70. Autio, K.A.; Pandit-Taskar, N.; Carrasquillo, J.A.; Stephenson, R.D.; Slovin, S.F.; Rathkopf, D.E.; Hong, C.; Heller, G.; Scher, H.I.; Larson, S.M.; et al. Repetitively dosed docetaxel and ${ }^{153}$ samarium-EDTMP as an antitumor strategy for metastatic castration-resistant prostate cancer. Cancer 2013, 119, 3186-3194. [CrossRef]

71. Baczyk, M.; Milecki, P.; Pisarek, M.; Gut, P.; Antczak, A.; Hrab, M. A prospective randomized trial: A comparison of the analgesic effect and toxicity of $153 \mathrm{Sm}$ radioisotope treatment in monotherapy and combined therapy including local external beam radiotherapy (EBRT) among metastatic castrate resistance prostate cancer (mCRPC) patients with painful bone metastases. Neoplasma 2013, 60, 328-333. [PubMed]

72. Rasulova, N.; Lyubshin, V.; Arybzhanov, D.; Sagdullaev, S.; Krylov, V.; Khodjibekov, M. Optimal timing of bisphosphonate administration in combination with samarium-153 oxabifore in the treatment of painful metastatic bone disease. World J. Nucl. Med. 2013, 12, 14-18. [CrossRef]

73. Baczyk, M.; Baczyk, E.; Sowiński, J. Preliminary results of combined application of radioisotopes and biphosphonates in the management of pain associated with osteoblastic-osteolytic bone metastases of breast cancer. Ortop. Traumatol. Rehabil. 2003, 5, 234-237.

74. Gallicchio, R.; Giacomobono, S.; Nardelli, A.; Pellegrino, T.; Simeon, V.; Gattozzi, D.; Maddalena, F.; Mainenti, P.; Storto, G. Palliative treatment of bone metastases with samarium-153 EDTMP at onset of pain. J. Bone Min. Metab. 2014, 32, 434-440. [CrossRef] [PubMed]

75. Han, S.H.; de Klerk, J.M.; Tan, S.; van het Schip, A.D.; Derksen, B.H.; van Dijk, A.; Kruitwagen, C.L.; Blijham, G.H.; van Rijk, P.P.; Zonnenberg, B.A. The PLACORHEN study: A double-blind, placebo-controlled, randomized radionuclide study with (186)Re-etidronate in hormone-resistant prostate cancer patients with painful bone metastases. Placebo Controlled Rhenium Study. J. Nucl. Med. 2002, 43, 1150-1156. [PubMed]

76. Sciuto, R.; Tofani, A.; Festa, A.; Giannarelli, D.; Pasqualoni, R.; Maini, C.L. Short-and long-term effects of 186Re-1, 1-hydroxyethylidene diphosphonate in the treatment of painful bone metastases. J. Nucl. Med. 2000, 41, 647-654.

77. Palmedo, H.; Bender, H.; Dierke-Dzierzon, C.; Carl, U.M.; Risse, J.; Krebs, D.; Biersack, H.J. Pain palliation with rhenium-186 HEDP in breast cancer patients with disseminated bone metastases. Clin. Nucl. Med. 1999, 24, 643-648. [CrossRef]

78. Pirayesh, E.; Amoui, M.; Mirzaee, H.R.; Tabei, F.; Rakhsha, A.; Kalantari, B.A.; Shafiei, B.; Assadi, M.; Asli, I.N. Phase 2 study of a high dose of 186Re-HEDP for bone pain palliation in patients with widespread skeletal metastases. J. Nucl. Med. Technol. 2013, 41, 192-196. [CrossRef]

79. Leondi, A.; Souvatzoglou, M.; Rapti, A.; Leontopoulou, S. Palliative treatment of painful disseminated bone metastases with^sup $186^{\wedge}$ Rhenium-HEDP in patients with lung cancer. Q. J. Nucl. Med. Mol. Imaging 2004, 48, 211.

80. Minutoli, F.; Herberg, A.; Spadaro, P.; Pecorella, G.R. [^ sup 186^ Re]-HEDP in the palliation of painful bone metastases from cancers other than prostate and breast. Q. J. Nucl. Med. Mol. Imaging 2006, 50, 355.

81. Han, S.H.; Zonneberg, B.A.; de Klerk, J.M.; Quirijnen, J.M.; van het Schip, A.D.; van Dijk, A.; Blijham, G.H.; van Rijk, P.P. 186Re-etidronate in breast cancer patients with metastatic bone pain. J. Nucl. Med. 1999, 40, 639-642. [PubMed]

82. Kolesnikov-Gauthier, H.; Carpentier, P.; Depreux, P.; Vennin, P.; Caty, A.; Sulman, C. Evaluation of toxicity and efficacy of 186Re-hydroxyethylidene diphosphonate in patients with painful bone metastases of prostate or breast cancer. J. Nucl. Med. 2000, 41, 1689-1694. [PubMed]

83. Ziada, G.; Faris, L.; Yacoub, S.; Elgazzar, A. Evaluation of efficacy and toxicity of treatment using Rhenium-186 HEDP in metastatic bone disease. Med. Princ. Pract. 1999, 8, 196-200. [CrossRef]

84. de Klerk, J.M.; van het Schip, A.D.; Zonnenberg, B.A.; van Dijk, A.; Stokkel, M.P.; Han, S.H.; Blijham, G.H.; van Rijk, P.P. Evaluation of thrombocytopenia in patients treated with rhenium-186-HEDP: Guidelines for individual dosage recommendations. J. Nucl. Med. 1994, 35, 1423-1428. [PubMed] 
85. Denis-Bacelar, A.M.; Chittenden, S.J.; Dearnaley, D.P.; Divoli, A.; O'Sullivan, J.M.; McCready, V.R.; Johnson, B.; Du, Y.; Flux, G.D. Phase I/II trials of 186 Re-HEDP in metastatic castration-resistant prostate cancer: Post-hoc analysis of the impact of administered activity and dosimetry on survival. Eur. J. Nucl. Med. Mol. Imaging 2017, 44, 620-629. [CrossRef]

86. Zafeirakis, A.; Zissimopoulos, A.; Baziotis, N.; Limouris, G.S. Management of metastatic bone pain with repeated doses of rhenium 186-HEDP in patients under therapy with zoledronic acid: A safe and additively effective practice. Cancer Biother. Radiopharm. 2009, 24, 543-550. [CrossRef]

87. van Dodewaard-de Jong, J.M.; de Klerk, J.M.H.; Bloemendal, H.J.; van Bezooijen, B.P.J.; de Haas, M.J.; Wilson, R.H.; O'Sullivan, J.M. A phase I study of combined docetaxel and repeated high activity 186Re-HEDP in castration-resistant prostate cancer (CRPC) metastatic to bone (the TAXIUM trial). Eur. J. Nucl. Med. Mol. Imaging 2011, 38, 1990-1998. [CrossRef]

88. Liepe, K.; G-Franke, W.; Kropp, J.; Koch, R.; Runge, R.; Hliscs, R. Comparison of rhenium-188, rhenium-186-HEDP and strontium-89 in palliation of painful bone metastases. Nuklearmedizin 2000, 39, 146-151.

89. Maxon, H.R.; Schroder, L.E.; Washburn, L.C.; Thomas, S.R.; Samaratunga, R.C.; Biniakiewicz, D.; Moulton, J.S.; Cummings, D.; Ehrhardt, G.J.; Morris, V. Rhenium-188 (Sn) HEDP for treatment of osseous metastases. J. Nucl. Med. 1998, 39, 659-663.

90. Savio, E.; Gaudiano, J.; Robles, A.M.; Balter, H.; Paolino, A.; López, A.; Hermida, J.C.; De Marco, E.; Martinez, G.; Osinaga, E. Re-HEDP: Pharmacokinetic characterization, clinical and dosimetric evaluation in osseous metastatic patients with two levels of radiopharmaceutical dose. BMC Nucl. Med. 2001, 1, 2. [CrossRef]

91. Liepe, K.; Hliscs, R.; Kropp, J.; Grüning, T.; Runge, R.; Koch, R.; Knapp, F.F., Jr.; Franke, W.-G. Rhenium-188-HEDP in the palliative treatment of bone metastases. Cancer Biother. Radiopharm. 2000, 15, 261-265. [CrossRef] [PubMed]

92. Zhang, H.; Tian, M.; Li, S.; Liu, J.; Tanada, S.; Endo, K. Rhenium-188-HEDP therapy for the palliation of pain due to osseous metastases in lung cancer patients. Cancer Biother. Radiopharm. 2003, 18, 719-726. [CrossRef] [PubMed]

93. Lange, R.; Overbeek, F.; de Klerk, J.M.; Pasker-de Jong, P.C.; van den Berk, A.M.; Ter Heine, R.; Rodenburg, C.J.; Kooistra, A.; Hendrikse, N.H.; Bloemendal, H.J. Treatment of painful bone metastases in prostate and breast cancer patients with the therapeutic radiopharmaceutical rhenium-188-HEDP. Nuklearmedizin 2016, 55, 188-195.

94. Cheng, A.; Chen, S.; Zhang, Y.; Yin, D.; Dong, M. The tolerance and therapeutic efficacy of rhenium-188 hydroxyethylidene diphosphonate in advanced cancer patients with painful osseous metastases. Cancer Biother. Radiopharm. 2011, 26, 237-244. [CrossRef] [PubMed]

95. Chen, S.; Xu, K.; Liu, W.; Yao, Z.; Chen, K.; Yin, D.; Wang, Y. Treatment of metastatic bone pain with rhenium-188 hydroxyethylidene diphosphonate. Med. Princ. Pract. 2001, 10, 98-101. [CrossRef]

96. Li, S.; Liu, J.; Zhang, H.; Tian, M.; Wang, J.; Zheng, X. Rhenium-188 HEDP To Treat Painful Bone Metastases. Clin. Nucl. Med. 2001, 26, 919-922. [CrossRef]

97. Palmedo, H.; Manka-Waluch, A.; Albers, P.; Schmidt-Wolf, I.G.; Reinhardt, M.; Ezziddin, S.; Joe, A.; Roedel, R.; Fimmers, R.; Knapp, F., Jr. Repeated bone-targeted therapy for hormone-refractory prostate carcinoma: Randomized phase II trial with the new, high-energy radiopharmaceutical rhenium-188 hydroxyethylidenediphosphonate. J. Clin. Oncol. 2003, 21, 2869-2875. [CrossRef]

98. Schwarz, B.; Ezziddin, S.; Ahmadzadehfar, H.; Näke, K.; Eskangi, M.; Müller, S.; Biersack, H.-J.; Palmedo, H. Repeated bone-targeted therapy for hormone refractory prostate cancer: Influence of rhenium-188 HEDP on prostate specific antigen. J. Nucl. Med. 2007, 48.

99. Biersack, H.-J.; Palmedo, H.; Andris, A.; Rogenhofer, S.; Knapp, F.F.; Guhlke, S.; Ezziddin, S.; Bucerius, J.; von Mallek, D. Palliation and survival after repeated 188Re-HEDP therapy of hormone-refractory bone metastases of prostate cancer: A retrospective analysis. J. Nucl. Med. 2011, 52, 1721-1726. [CrossRef]

100. Jong, J.M.va.; de Klerk, J.M.H.; Bloemendal, H.J.; Oprea-Lager, D.E.; Hoekstra, O.S.; van den Berg, H.P.; Los, M.; Beeker, A.; Jonker, M.A.; O'Sullivan, J.M. A randomised, phase II study of repeated rhenium-188-HEDP combined with docetaxel and prednisone versus docetaxel and prednisone alone in castration-resistant prostate cancer (CRPC) metastatic to bone; the Taxium II trial. Eur. J. Nucl. Med. Mol. Imaging 2017, 44, 1319-1327. [CrossRef]

101. Liang, J.; Jiang, N.; JQ, D.; Lu, X.; Liu, X.; Chen, S. Clinical value of combined therapy with 188Re-HEDP and pamidronate in breast cancer with bone metastasis. Zhonghua Zhong Liu Za Zhi Chin. J. Oncol. 2005, 27, 180-182.

102. Kochetova, T.; Krylov, V.; Smolyarchuk, M.; Sokov, D.; Lunev, A.; Shiryaev, S.; Kruglova, O.; Makeenkova, T.; Petrosyan, K.; Dolgova, A. 188Re zoledronic acid in the palliative treatment of painful bone metastases. Int. J. Nucl. Med. Res. 2017, 92-100. [CrossRef] 
103. Chakraborty, S.; Das, T.; Banerjee, S.; Balogh, L.; Chaudhari, P.R.; Sarma, H.D.; Polyák, A.; Máthé, D.; Venkatesh, M.; Janoki, G. 177Lu-EDTMP: A viable bone pain palliative in skeletal metastasis. Cancer Biother. Radiopharm. 2008, 23, 202-213. [CrossRef] [PubMed]

104. Sharma, S.; Singh, B.; Koul, A.; Mittal, B.R. Comparative therapeutic efficacy of 153Sm-EDTMP and 177Lu-EDTMP for bone pain palliation in patients with skeletal metastases: Patients' pain score analysis and personalized dosimetry. Front. Med. 2017, 4, 46. [CrossRef]

105. Singh, B.; Prashar, S.; Koul, A.; Mittal, B. Comparative therapeutic efficacy of 177Lu-EDTMP and 153Sm-EDTMP in bone pain palliation in cancer patients with multiple skeletal metastases. J. Nucl. Med. 2016, 57, 1441.

106. Thapa, P.; Nikam, D.; Das, T.; Sonawane, G.; Agarwal, J.P.; Basu, S. Clinical efficacy and safety comparison of 177Lu-EDTMP with 153Sm-EDTMP on an equidose basis in patients with painful skeletal metastases. J. Nucl. Med. 2015, 56, 1513-1519. [CrossRef]

107. Alavi, M.; Khajeh-Rahimi, F.; Yousefnia, H.; Mohammadianpanah, M.; Zolghadri, S.; Bahrami-Samani, A.; Ghannadi-Maragheh, M. 177Lu/153Sm-Ethylenediamine Tetramethylene Phosphonic Acid Cocktail: A Novel Palliative Treatment for Patients with Bone Metastases. Cancer Biother. Radiopharm. 2019, 34, 280-287. [CrossRef]

108. Khawar, A.; Eppard, E.; Roesch, F.; Ahmadzadehfar, H.; Kürpig, S.; Meisenheimer, M.; Gaertner, F.C.; Essler, M.; Bundschuh, R.A. Biodistribution and post-therapy dosimetric analysis of [177 Lu] Lu-DOTA ZOL in patients with osteoblastic metastases: First results. Ejnmmi Res. 2019, 9, 102. [CrossRef]

109. Liu, C.; Brašic, J.R.; Liu, X.; Li, H.; Xiang, X.; Luo, Z.; Wang, Y.; Kuai, D.; Zhang, G.; Zaknun, J.J. Timing and optimized acquisition parameters for the whole-body imaging of 177Lu-EDTMP toward performing bone pain palliation treatment. Nucl. Med. Commun. 2012, 33, 90-96. [CrossRef]

110. Sadremomtaz, A.; Masoumi, M. Comparison between Targeted Radionuclide Therapy of Bone Metastases Based on $\beta$-Emitting and $\alpha$-Emitting Radionuclides. J. Med. Imaging Radiat. Sci. 2019, 50, 272-279. [CrossRef]

111. Yousefnia, H.; Amraei, N.; Hosntalab, M.; Zolghadri, S.; Bahrami-Samani, A. Preparation and biological evaluation of 166Ho-BPAMD as a potential therapeutic bone-seeking agent. J. Radioanal. Nucl. Chem. 2015, 304, 1285-1291. [CrossRef]

112. Zolghadri, S.; Jalilian, A.R.; Naseri, Z.; Yousefnia, H.; Bahrami-Samani, A.; Ghannadi-Maragheh, M.; Afarideh, H. Production, quality control and biological evaluation of 166Ho-PDTMP as a possible bone palliation agent. Iran. J. Basic Med. Sci. 2013, 16, 719. [PubMed]

113. Pedraza-López, M.; Ferro-Flores, G.; de Murphy, C.A.; Tendilla, J.I.; Villanueva-Sánchez, O. Preparation of 166Dy/166Ho-EDTMP: A potential in vivo generator system for bone marrow ablation. Nucl. Med. Commun. 2004, 25, 615-621. [CrossRef] [PubMed]

114. Giralt, S.; Bensinger, W.; Goodman, M.; Podoloff, D.; Eary, J.; Wendt, R.; Alexanian, R.; Weber, D.; Maloney, D.; Holmberg, L. 166Ho-DOTMP plus melphalan followed by peripheral blood stem cell transplantation in patients with multiple myeloma: Results of two phase 1/2 trials. Blood 2003, 102, 2684-2691. [CrossRef] [PubMed]

115. Elgazzar, A.H. Therapeutic Use of Radionuclides in Bone and Joint Disease. In Orthopedic Nuclear Medicine; Springer: Berlin/Heidelberg, Germany, 2017; pp. 387-415.

116. Bagheri, R.; Jalilian, A.R.; Bahrami-Samani, A.; Mazidi, M.; Ghannadi-Maragheh, M. Production of Holmium-166 DOTMP: A promising agent for bone marrow ablation in hematologic malignancies. Iran. J. Nucl. Med. 2011.

117. Klaassen, N.J.M.; Arntz, M.J.; Gil Arranja, A.; Roosen, J.; Nijsen, J.F.W. The various therapeutic applications of the medical isotope holmium-166: A narrative review. Ejnmmi Radiopharm. Chem. 2019, 4, 19. [CrossRef]

118. Ueno, N.T.; De Souza, J.A.; Booser, D.; Nakayama, K.; Madewell, J.; Wendt III, R.E.; Hortobagyi, G.N.; Podoloff, D.; Champlin, R.E. Pilot study of targeted skeletal radiation therapy for bone-only metastatic breast cancer. Clin. Breast Cancer 2009, 9, 173-177. [CrossRef]

119. Du, Y.; Carrio, I.; De Vincentis, G.; Fanti, S.; Ilhan, H.; Mommsen, C.; Nitzsche, E.; Sundram, F.; Vogel, W.; Oyen, W.; et al. Practical recommendations for radium-223 treatment of metastatic castration-resistant prostate cancer. Eur. J. Nucl. Med. Mol. Imaging 2017, 44, 1671-1678. [CrossRef]

120. Nilsson, S.; Sartor, A.O.; Bruland, O.S.; Fang, F.; Aksnes, A.-K.; Parker, C. Pain analyses from the phase III randomized ALSYMPCA study with radium-223 dichloride (Ra-223) in castration-resistant prostate cancer (CRPC) patients with bone metastases. Am. Soc. Clin. Oncol. 2013. [CrossRef] 
121. Nilsson, S.; Cislo, P.; Sartor, O.; Vogelzang, N.; Coleman, R.; O'Sullivan, J.; Reuning-Scherer, J.; Shan, M.; Zhan, L.; Parker, C. Patient-reported quality-of-life analysis of radium-223 dichloride from the phase III ALSYMPCA study. Ann. Oncol. 2016, 27, 868-874. [CrossRef]

122. Parker, C.; Nilsson, S.; Heinrich, D.; Helle, S.I.; O'sullivan, J.; Fosså, S.D.; Chodacki, A.; Wiechno, P.; Logue, J.; Seke, M.; et al. Alpha emitter radium-223 and survival in metastatic prostate cancer. N. Engl. J. Med. 2013, 369, 213-223. [CrossRef] [PubMed]

123. Shore, N.D. Radium-223 dichloride for metastatic castration-resistant prostate cancer: The urologist's perspective. Urology 2015, 85, 717-724. [CrossRef] [PubMed]

124. Renzulli, J.F., II; Collins, J.; Mega, A. Radium-223 dichloride: Illustrating the benefits of a multidisciplinary approach for patients with metastatic castration-resistant prostate cancer. J. Multidiscip. Healthc. 2015, 8, 279. [CrossRef] [PubMed]

125. Dizdarevic, S.; Jessop, M.; Begley, P.; Main, S.; Robinson, A. ${ }^{223}$ Ra-Dichloride in castration-resistant metastatic prostate cancer: Improving outcomes and identifying predictors of survival in clinical practice. Eur. J. Nucl. Med. Mol. Imaging 2018, 45, 2264-2273. [CrossRef]

126. Heidenreich, A.; Gillessen, S.; Heinrich, D.; Keizman, D.; O'Sullivan, J.M.; Carles, J.; Wirth, M.; Miller, K.; Reeves, J.; Seger, M.; et al. Radium-223 in asymptomatic patients with castration-resistant prostate cancer and bone metastases treated in an international early access program. BMC Cancer 2019, 19, 12. [CrossRef]

127. Parker, C.; Heidenreich, A.; Nilsson, S.; Shore, N. Current approaches to incorporation of radium-223 in clinical practice. Prostate Cancer Prostatic Dis. 2018, 21, 37-47. [CrossRef]

128. Blackledge, M.; Kohl, D.; Collins, D.; Scurr, E.; Hughes, J.; Leach, M. Assessing response heterogeneity following radium 223 administration using whole body diffusion weighted MRI. In Proceedings of the International Society for Magnetic Resonance in Medicine 25th Annual Meeting \& Exhibition, Honolulu, HI, USA, 22-27 April 2017.

129. Pezaro, C.J.; Omlin, A.; Lorente, D.; Rodrigues, D.N.; Ferraldeschi, R.; Bianchini, D.; Mukherji, D.; Riisnaes, R.; Altavilla, A.; Crespo, M.; et al. Visceral disease in castration-resistant prostate cancer. Eur. Urol. 2014, 65, $270-273$. [CrossRef]

130. Morris, M.J.; Corey, E.; Guise, T.A.; Gulley, J.L.; Kelly, W.K.; Quinn, D.I.; Scholz, A.; Sgouros, G. Radium-223 mechanism of action: Implications for use in treatment combinations. Nat. Rev. Urol. 2019, 1-12. [CrossRef]

131. Coutinho, I.; Day, T.K.; Tilley, W.D.; Selth, L.A. Androgen receptor signaling in castration-resistant prostate cancer: A lesson in persistence. Endocr. Relat. Cancer 2016, 23, T179-T197. [CrossRef]

132. Saad, F.; Carles, J.; Gillessen, S.; Heidenreich, A.; Heinrich, D.; Gratt, J.; Lévy, J.; Miller, K.; Nilsson, S.; Petrenciuc, O.; et al. Radium-223 and concomitant therapies in patients with metastatic castration-resistant prostate cancer: An international, early access, open-label, single-arm phase $3 \mathrm{~b}$ trial. Lancet Oncol. 2016, 17, 1306-1316. [CrossRef]

133. Sartor, O.; Vogelzang, N.J.; Sweeney, C.; Fernandez, D.C.; Almeida, F.; Iagaru, A.; Brown, A., Jr.; Smith, M.R.; Agrawal, M.; Dicker, A.P.; et al. Radium-223 safety, efficacy, and concurrent use with abiraterone or enzalutamide: First US experience from an expanded access program. Oncologist 2018, 23, 193. [CrossRef] [PubMed]

134. Smith, M.; Parker, C.; Saad, F.; Miller, K.; Tombal, B.; Ng, Q.S.; Boegemann, M.; Matveev, V.; Piulats, J.M.; Zucca, L.E. Addition of radium-223 to abiraterone acetate and prednisone or prednisolone in patients with castration-resistant prostate cancer and bone metastases (ERA 223): A randomised, double-blind, placebo-controlled, phase 3 trial. Lancet Oncol. 2019, 20, 408-419. [CrossRef]

135. Paganelli, G.; Rossetti, C.; Aglietta, M.; Messina, C.; Versari, A.; Michalski, J.; O’Sullivan, J.; Parker, C.; Garcia-Vargas, J.; Sartor, A.; et al. External beam radiation therapy (EBRT) use and safety with radium-223 dichloride (Ra-223) in patients (pts) with castration-resistant prostate cancer (CRPC) and symptomatic bone metastases (mets) from the ALSYMPCA trial. Ann. Oncol. 2015, 26, vi61. [CrossRef]

136. Sartor, O.; Coleman, R.; Nilsson, S.; Heinrich, D.; Helle, S.I.; O'Sullivan, J.M.; Fosså, S.D.; Chodacki, A.; Wiechno, P.; Logue, J.; et al. Effect of radium-223 dichloride on symptomatic skeletal events in patients with castration-resistant prostate cancer and bone metastases: Results from a phase 3, double-blind, randomised trial. Lancet Oncol. 2014, 15, 738-746. [CrossRef]

137. Hoskin, P.; Sartor, O.; O'Sullivan, J.M.; Johannessen, D.C.; Helle, S.I.; Logue, J.; Bottomley, D.; Nilsson, S.; Vogelzang, N.J.; Fang, F.J.; et al. Efficacy and safety of radium-223 dichloride in patients with castration-resistant prostate cancer and symptomatic bone metastases, with or without previous docetaxel use: A prespecified subgroup analysis from the randomised, double-blind, phase 3 ALSYMPCA trial. Lancet Oncol. 2014, 15, 1397-1406. [PubMed] 
138. Morris, M.J.; Loriot, Y.; Sweeney, C.J.; Fizazi, K.; Ryan, C.J.; Shevrin, D.H.; Antonarakis, E.S.; Pandit-Taskar, N.; Deandreis, D.; Jacene, H.A.; et al. Radium-223 in combination with docetaxel in patients with castration-resistant prostate cancer and bone metastases: A phase 1 dose escalation/randomised phase 2a trial. Eur. J. Cancer 2019, 114, 107-116. [CrossRef]

139. Morris, M.J.; Loriot, Y.; Sweeney, C.; Fizazi, K.; Ryan, C.J.; Shevrin, D.H.; Antonarakis, E.S.; Reeves, J.; Chandrawansa, K.; Kornacker, M. Updated results: A phase I/Ila randomized trial of radium-223+ docetaxel versus docetaxel in patients with castration-resistant prostate cancer and bone metastases. Am. Soc. Clin. Oncol. 2016. [CrossRef]

140. Coleman, R.; Brown, J.; Rathbone, E.; Flanagan, L.; Reid, A.; Kendall, J.; Howell, S.; Twelves, C.; Palmieri, C.; Anand, A.; et al. CApecitabine plus Radium-223 (Xofigo ${ }^{\mathrm{TM}}$ ) in breast cancer patients with BONe metastases (CARBON): Study protocol for a phase IB/IIA randomised controlled trial. Trials 2020, 21, 89. [CrossRef]

141. Ueno, N.T.; Tahara, R.K.; Fujii, T.; Reuben, J.M.; Gao, H.; Saigal, B.; Lucci, A.; Iwase, T.; Ibrahim, N.K.; Damodaran, S.; et al. Phase II study of Radium-223 dichloride combined with hormonal therapy for hormone receptor-positive, bone-dominant metastatic breast cancer. Cancer Med. 2020, 9, 1025-1032. [CrossRef]

142. Taber, A.; Khurshid, H.; Noto, R.; Yoo, D.; Dipetrillo, T.; Safran, H.; Center, C. BrUOG L301: Xofigo Following Frontline-Line Chemotherapy For Patients With Non-Small Cell Lung Cancer and Bone Metastases. ClinicalTrials.gov 2015. identifier NCT02283749.

143. Turner, J.H.; Martindale, A.A.; Sorby, P.; Hetherington, E.L.; Fleay, R.F.; Hoffman, R.F.; Claringbold, P.G. Samarium-153 EDTMP therapy of disseminated skeletal metastasis. Eur. J. Nucl. Med. 1989, 15, 784-795. [CrossRef] [PubMed]

144. Maxon, H., 3rd; Schroder, L.; Thomas, S.; Hertzberg, V.; Deutsch, E.; Scher, H.; Samaratunga, R.; Libson, K.; Williams, C.; Moulton, J. Re-186 (Sn) HEDP for treatment of painful osseous metastases: Initial clinical experience in 20 patients with hormone-resistant prostate cancer. Radiology 1990, 176, 155-159. [CrossRef] [PubMed]

145. Nilsson, S.; Larsen, R.H.; Fosså, S.D.; Balteskard, L.; Borch, K.W.; Westlin, J.-E.; Salberg, G.; Bruland, Ø.S. First clinical experience with $\alpha$-emitting radium-223 in the treatment of skeletal metastases. Clin. Cancer Res. 2005, 11, 4451-4459. [CrossRef] [PubMed]

146. van Dodewaard-de Jong, J.M.; Oprea-Lager, D.E.; Hooft, L.; de Klerk, J.M.; Bloemendal, H.J.; Verheul, H.M.; Hoekstra, O.S.; van den Eertwegh, A.J. Radiopharmaceuticals for palliation of bone pain in patients with castration-resistant prostate cancer metastatic to bone: A systematic review. Eur. Urol. 2016, 70, 416-426. [CrossRef]

147. Rossi, L.; Longhitano, C.; Kola, F.; Del Grande, M. State of art and advances on the treatment of bone metastases from breast cancer: A concise review. Chin. Clin. Oncol. 2020, 9. [CrossRef]

(C) 2020 by the authors. Licensee MDPI, Basel, Switzerland. This article is an open access article distributed under the terms and conditions of the Creative Commons Attribution (CC BY) license (http://creativecommons.org/licenses/by/4.0/). 